OCCASIONAL PAPER

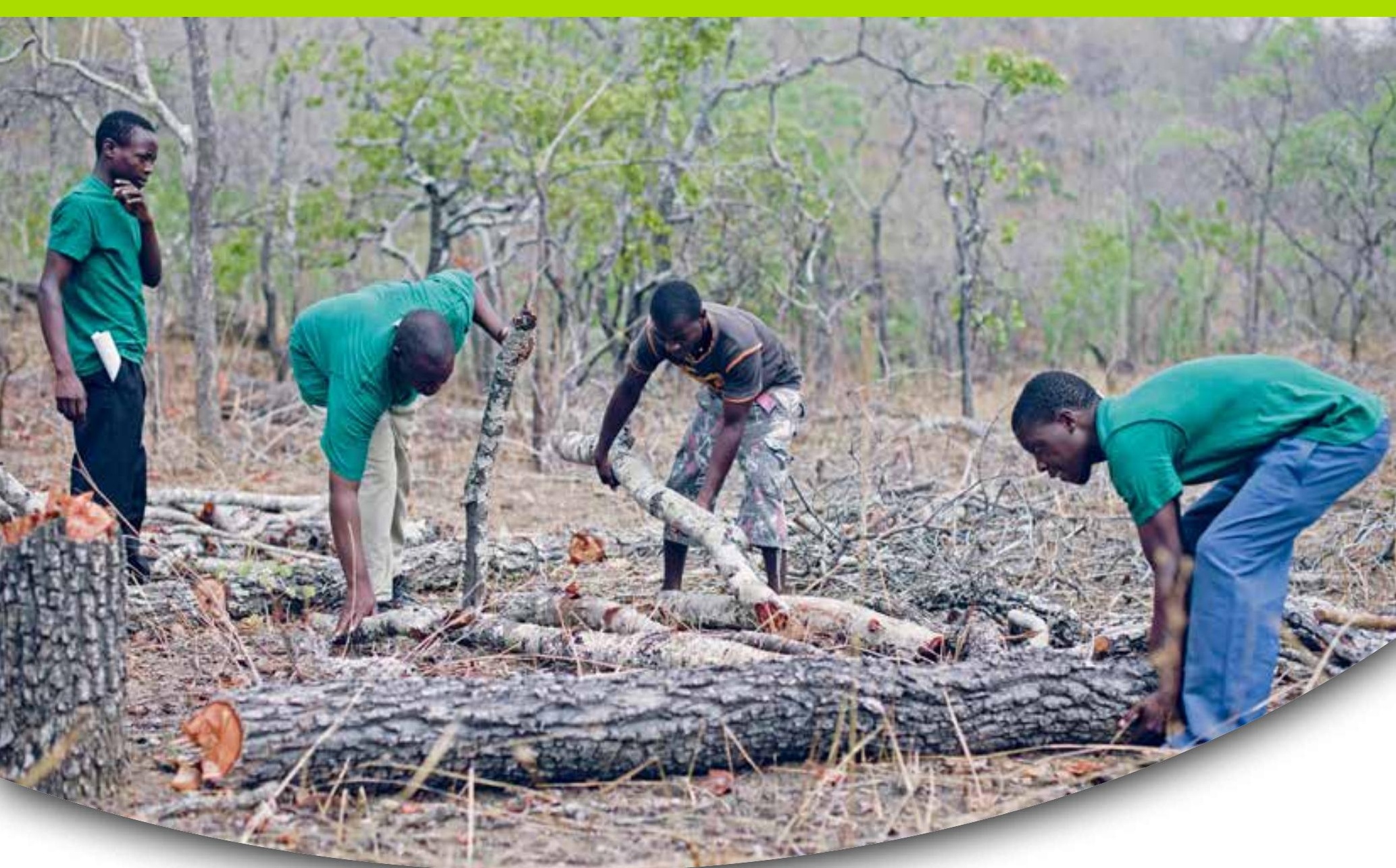

\title{
Building enabling legal frameworks for sustainable land-use investments in Zambia, Tanzania and Mozambique
}

\section{A synthesis}

M Cecilia G Dalupan

Caroline Haywood

D Andrew Wardell

Marie-Claire Cordonnier-Segger

Robert Kibugi

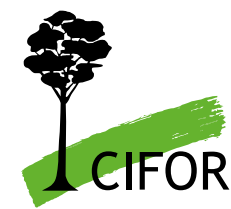





\section{Building enabling legal frameworks for sustainable land-use investments in Zambia, Tanzania and Mozambique} A synthesis

M Cecilia G Dalupan

IDLO

Caroline Haywood

IDLO

D Andrew Wardell

CIFOR

Marie-Claire Cordonnier-Segger

IDLO

Robert Kibugi

IDLO 
Occasional Paper 140

(c) 2015 Center for International Forestry Research

(c) (i) Content in this publication is licensed under a Creative Commons Attribution 4.0 International (CC BY 4.0), http://creativecommons.org/licenses/by/4.0/

ISBN 978-602-387-015-8

DOI: $10.17528 /$ cifor/005753

Dalupan MCG, Haywood C, Wardell DA, Cordonnier-Segger M-C and Kibugi R. 2015. Building enabling legal frameworks for sustainable land-use investments in Zambia, Tanzania and Mozambique: A synthesis.

Occasional Paper 140. Bogor, Indonesia: CIFOR.

Photo by Ollivier Girard/CIFOR

Charcoal production, Zuwalinyenga, Zambia.

\author{
CIFOR \\ Jl. CIFOR, Situ Gede \\ Bogor Barat 16115 \\ Indonesia \\ $\mathrm{T}+62(251) 8622-622$ \\ $F+62(251) 8622-100$ \\ E cifor@cgiar.org
}

\title{
cifor.org
}

We would like to thank all funding partners who supported this research through their contributions to the CGIAR Fund. For a full list of the 'CGIAR Fund' funding partners please see: http://www.cgiar.org/who-we-are/cgiar-fund/fund-donors-2/

Any views expressed in this publication are those of the authors. They do not necessarily represent the views of CIFOR, the editors, the authors' institutions, the financial sponsors or the reviewers. 


\section{Contents}

Acknowledgments vii

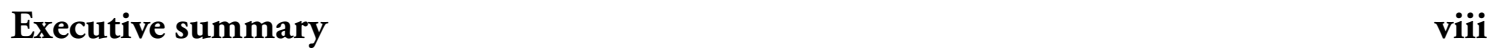

$\begin{array}{ll}\text { Key insights } & \text { ix }\end{array}$

1 Introduction 1

2 Landscapes and rule of law: The elements of sustainable investments 3

3 Laying the foundation for sustainable investments:

4 Sustainable land-use investments: Key challenges and opportunities 7

$\begin{array}{lll}4.1 & \text { Incentives for sustainable investments } & 7\end{array}$

$\begin{array}{ll}4.2 \text { Security of customary land tenure } & 14\end{array}$

4.3 Enforcement of socioeconomic and environmental safeguards 20

$\begin{array}{ll}4.4 & \text { Public awareness and participation } \\ & 26\end{array}$

5 Implications of key findings for future action 30

6 Concluding remarks 33

7 References $\quad 34$ 


\section{List of figures, tables and boxes}

\section{Figures}

1 Illustrative elements of a sustainable investment 3

2 Landscapes governance and sustainable land-use investments 4

3 Barriers to sustainable land-use investments $\quad 7$

\section{Tables}

1 General overview of resource sectors (IDLO and CIFOR 2015) 5

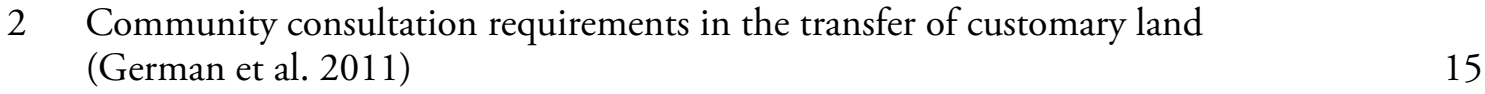

3 General frameworks for dispute resolution (German et al. 2011) 20

4 Strengthening legal frameworks, building institutions and empowering
communities for sustainable investments

\section{Boxes}

1 Beekeeping in Tanzania $\quad 10$

2 Charcoal production in the East Arc Mountain Blocks (Schaafsma et al. 2012) 10

3 Outgrower arrangements 11

4 The citizens economic empowerment commission (CEEC) 13

5 Loss of customary land rights 16

6 Vulnerability of undocumented land rights to fraud $\quad 17$

7 Displacement of Capanga villagers $\quad 18$

8 Failed compensation arrangements 19

9 Overlapping land designations in the Massingir pistrict of Gaza province 21

10 Withdrawal of the Lusaka South Forest Reserve 26 21

11 Mining in the Lower Zambezi National Park 23

12 BioCarbon Partners' (BCP) Lower Zambezi REDD+ Project 27 


\section{List of abbreviations}

\begin{tabular}{|c|c|}
\hline ASM & artisanal and small-scale mining \\
\hline $\mathrm{BCP}$ & BioCarbon Partners \\
\hline BIT & Bilateral Investment Treaty \\
\hline CBFM & community-based forest management \\
\hline CEEC & Citizens Economic Empowerment Commission \\
\hline CGC & community management committee \\
\hline CIFOR & Center for International Forestry Research \\
\hline CONDES & National Council for Sustainable Development \\
\hline CPI & Investments Promotion Centre \\
\hline DNTF & National Directorate of Land and Forest \\
\hline DUAT & Direito de uso e aproveitamento da terra (Right to use and benefit from the land) \\
\hline EAM & East Arc Mountain Blocks \\
\hline EIA & environment impact assessment \\
\hline EITI & Zambia Extractive Industries Transparency Initiative \\
\hline EMA & Environment Management Act \\
\hline ESIA & environmental and social impact assessment \\
\hline FBD & Forest and Beekeeping Division \\
\hline FMP & forest management plan \\
\hline FPIC & free, prior, informed consent \\
\hline FUNAE & National Fund for Rural Electrification \\
\hline GDP & gross domestic product \\
\hline ha & hectares \\
\hline IDLO & International Development Law Organization \\
\hline IPPA & investment protection and promotion agreement \\
\hline JFM & joint forest management \\
\hline KASCOL & Kaleya Smallholders Company Ltd. \\
\hline MSMEs & micro, small and medium enterprises \\
\hline MW & megawatt \\
\hline $\mathrm{MZN}$ & Mozambican Metical \\
\hline NEMC & National Environmental Management Council \\
\hline
\end{tabular}


OECD Organisation for Economic Co-operation and Development

PFM participatory forest management

PLUP participatory land-use planning

PSDRP Private Sector Development Reform Programme

PV photovoltaic

RE renewable energy

REDD+ Reducing Emissions from Deforestation and Forest Degradation "Plus" Conservation

SACCOS Savings and Credit Cooperative Societies

SAGCOT Southern Agricultural Growth Corridor of Tanzania

SL simple license

SPP Small Power Project

TANESCO Tanzania Electricity Supply Company

TIA Tanzania Investment Act

TIC Tanzania Investment Centre

TSH Tanzanian Shilling

UNFCCC United Nations Framework Convention on Climate Change

USD United States Dollar

VAT value added tax

ZDA Zambia Development Act

ZDAg Zambia Development Agency

ZMW Zambian Kwacha

ZSC Zambia Sugar Company

AfDB African Development Bank 


\section{Acknowledgments}

This report is the product of collaboration among legal researchers from a number of different countries and academic institutions.

IDLO and CIFOR would like to acknowledge the important contributions of Dr. Eduardo Chiziane, lead legal expert in Mozambique, Dr. Robert Kibugi and Ms. Joyce Maselle, lead legal experts in Tanzania and Dr. Pamela Towela Sambo, lead legal expert in Zambia. We would also like to thank Dr. George Schoneveld for comments to an earlier draft and the legal students who provided research support from the Universidade
Eduardo Mondlane, the Open University of Tanzania, the University of Dar es Salaam and the University of Zambia.

IDLO and CIFOR would also like to thank the civil society organizations, investors, academics and government officials in Mozambique, Tanzania and Zambia who shared stakeholder perspectives by participating in interviews and workshops.

Finally, IDLO and CIFOR extend appreciation to the DFID Know-For Program for financial support in undertaking this research project. 


\section{Executive summary}

The International Development Law Organization (IDLO) and the Center for International Forestry Research (CIFOR) assessed the legal frameworks for major resource sectors in Zambia, Tanzania and Mozambique to analyze whether and to what extent they enable sustainable investments. Relevant international standards suggest that sustainable investments integrate socioeconomic and environmental concerns, bound together by the rule of law. This calls for landscapes governance, which considers all stakeholders, interests and competing resource uses, under which the traditional model of investment decisions based solely on economic goals is broadened considerably to place communities and environmental concerns at the very heart of the process.

These countries' national development plans and their crosscutting laws on land and the environment incorporate principles of sustainable development. Their sector-specific laws governing forestry, agriculture, mining and energy reflect these principles to varying degrees. Relying significantly on these sectors, these countries have witnessed consistent GDP growth in recent years. Despite their resource wealth and increased investments, poverty and resource degradation persist. Rural populations remain disproportionately affected, with limited access to basic services and increased vulnerability to the impacts of deforestation and climate change.

Here we outline key insights on four common issues identified by the legal assessments that can hinder or enable sustainable landuse investments. These consist of investment incentives, security of customary land tenure, enforcement of socioeconomic and environmental safeguards, and public awareness and participation. These issues also present rule of law opportunities to support landscapes governance aimed at empowering communities, alleviating poverty and contributing to sustainable development. 


\section{Key insights}

\section{Reframing investment incentives and focusing on smallholder interests}

- Development priorities in forestry, agriculture, energy and mining are determined largely by central authorities, with continued preference for large land-use investments in rural areas. Legal reforms and participatory processes can help refocus investment frameworks to support community empowerment and cleaner technologies as drivers for sustainable development.

- Limited incentives and investment opportunities are available for communitybased medium, small and micro enterprises, although these are more likely to facilitate public participation and improve livelihoods. Empowered communities with decision-making responsibilities and ownership can contribute meaningfully to sustainable investments.

- To improve investment opportunities for rural communities, it is necessary to address credit and financial barriers, improve the valuation of resource-based goods and services and establish appropriate incentives. The structure of revenue allocation between central and local authorities needs to be reviewed so that more funds can be re-invested locally.

\section{Protecting customary land rights and ensuring consultation and consent}

- The acquisition of land for investments is largely driven by investors, government authorities and local leaders. Despite consent or consultation safeguards, communities with customary land rights are vulnerable to dispossession due to elite capture, low public awareness and lack of transparency on land acquisition processes. Enforcement challenges also hinder the effectiveness of safeguards, including lack of guidance on the scope of consultations, adequacy of community representation and the exclusion of women and/ or other marginalized groups. The enforcement of clear implementing regulations is necessary to address these uncertainties.

- The insecurity of customary land rights is related to their lack of documentation. Formalization of these rights can potentially increase security of tenure, but safeguards against elite capture need to be incorporated. Access to transparent and effective documentation of customary land rights will help both rights holders and investors.

- Policies and clear operational guidelines need to internalize safeguards against involuntary resettlement due to land-use investments, accounting for both physical and economic displacement. Resettlement can occur only as a last option and in the most compelling circumstances. It requires the informed consent of affected communities and should not result in increased impoverishment.

- Access to appropriate and effective dispute resolution mechanisms is necessary to protect rights to land. The effectiveness of these mechanisms is hampered by the lack of clear regulations that ensure the credibility of the process and the limited financial and technical capacity of arbiters to carry out their responsibilities.

\section{Establishing clear and effective regulations, strengthening enforcement capacity and supporting decentralization}

- Competing institutional mandates and overlapping jurisdictions can create uncertainty, providing multiple investment entry points that increase monitoring challenges. Institutional mandates need to be reviewed and streamlined and mechanisms for institutional coordination strengthened. Beyond ensuring 
that land-use investments mitigate adverse impacts, more focus is needed on institutional capacity to capture and maximize benefits from these investments, especially for affected communities.

- As the scale of land-use investments increases, decision-making processes become more centralized and tend to reduce the participation of local authorities and affected communities. Effective devolution of enforcement authority requires the harmonization of national and subnational laws and regulations, as well as strengthened financial and human resources at the local level.

- Given the continued preference for largescale land-use investments, political will is especially critical when competing interests pit, rather than integrate, economic concerns against environmental values. Strong advocates or champions committed to sustainable development options are needed in government, civil society and the private sector.

- The EIA requirement is a positive step toward creating the conditions for sustainable investments, but its effectiveness is hampered by significant challenges, including low public awareness, lack of government personnel and consultants and limited financial resources.

- Resource-related conflicts can arise when communities impacted most by land-use investments have no role, participation or benefits from them. Sustainable investments call for an equitable distribution of wealth and co-benefits for affected communities. Legal requirements that entitle them to a share of investment revenue are rare, but they can be a powerful socioeconomic safeguard that can strengthen the position of communities and ensures that their benefits are not solely dependent on their capacity to negotiate.

\section{Raising awareness, guaranteeing participation and promoting freedom of information}

- Participatory land-use planning and similar approaches support the exchange of information and partnerships among diverse stakeholders. These can support capacity building for communities, develop collaborative mechanisms and serve as a forum to address disputes. Given the centralized nature of decisionmaking over large land-use investments, these participatory efforts need to be linked across governance levels.

- Adequate representation of communities, timely dissemination of information and awareness of cultural sensitivities, significantly impact public consultation processes relating to landuse decisions. It is critical that public comments and concerns are genuinely documented and considered.

- Sustainable investments require transparency and yet there are no laws in Zambia, Tanzania and Mozambique that broadly guarantee access to information. Freedom of information laws can help improve access to noncommercial confidential information about investments and build the capacity of civil society and the public to hold investors, traditional leaders and government authorities accountable.

This report demonstrates that landscapes governance embodying the rule of law and adherence to social and environmental safeguards can create enabling conditions for sustainable investments. Equity, responsive legal and policy reforms, improved enforcement capacity, strengthened participatory mechanisms and other rule of law considerations are critical to planning and managing investments so that they contribute to sustainable development. 


\section{Introduction}

Global demand for resource-based products is on the rise. Primary energy consumption grew by almost $30 \%$ in the first decade of this century and is estimated to increase at a similar rate by 2035 (OECD and IEA 2012). The demand for copper has more than tripled since the 1980s due to its widespread use in industrial and consumer products (ICSG 2013). In developing countries, forest plantations expanded by more than $50 \%$ between 1990 and 2010 (World Rainforest Movement 2012; Castrén et al. 2014). About 4.1 million ha were available annually for large-scale farming from 1961 to 2007, with investment deals in Africa alone covering 39.7 million ha in 2009 (Arezki et al. 2012). Foreign investments in the continent amounted to USD 50 billion in 2012, driven in part by the extractive sectors (UNCTAD 2013).

Large-scale land-use investments are sought not only by investors but by developing country governments whose national plans rely on these resource sectors to drive economic growth. These investments can be challenging and controversial, however, given their impact on ecosystems and livelihoods of small-scale land users. An estimated 2 billion people continue to rely on small-scale farming (Vorley et al. 2012) while around 350 million of the world's poorest rely on forests for fuel, food, water, wood and other basic needs (Chao 2012).

While investments in natural resources may generate employment opportunities and other benefits, these do not necessarily contribute to sustainable development. This is especially the case for forestry, agriculture, mining and energy projects - these often require large tracts of land and are typically governed by separate sectoral legal frameworks that do not integrate competing land uses or local socioeconomic and environmental concerns. Moreover, these projects are increasingly located in rural areas inhabited by communities who are unfamiliar with large investments, whose land rights may be undocumented and who have historically been excluded from development decisions affecting them.

This fragmented approach runs counter to longterm landscapes governance that can enable sustainable investments by integrating broader social, economic and environmental objectives under the rule of law. Approaches that focus instead on investments within a specific resource sector, with little to no consideration of other sectors or local concerns, give rise to a broad range of impacts on communities, including physical and economic displacement, pollution, deforestation, biodiversity loss and conflicts over land rights. Large-scale land-use investments resulting in such negative effects may be found throughout the developing world and it is important to understand the legal frameworks within which these occur in order to identify both the barriers to and the opportunities for sustainable landscapes governance.

The International Development Law Organization (IDLO) and the Center for International Forestry Research (CIFOR) thus embarked on a project to assess the legal frameworks for forestry, agriculture, mining and energy in Zambia, Tanzania and Mozambique (Annex A), and opportunities there for more sustainable landscapes governance. While these countries are distinct in significant ways, ${ }^{1}$ they are geographic neighbors with comparable socioeconomic conditions that rely heavily on land-use investments in natural resources. They have undertaken reforms in pursuit of sustainable development, but despite increased investments, poverty and resource degradation persist. These

1 Unlike Tanzania and Zambia whose formal legal systems are based on common law, Mozambique's is based on civil law. All three recognize legal pluralism (see www.law.cornell. edu/world/Africa). 
factors rendered them ideal for an assessment of the rule of law challenges and opportunities that may hinder or help land-use investments to contribute to sustainable development.

This project began with inception workshops in each country to guide the methodological approach of the assessments. The assessments then employed a consistent methodology, in collaboration with incountry legal experts and researchers. The research teams analyzed relevant policies, laws, reports and case studies on land-use investments across the four sectors in each country. They met with representatives of community organizations, civil society, concerned government agencies, academic institutions and the private sector. Due to the broad scope of work and time constraints, the research teams had limited opportunities for direct consultations with communities. Opportunities for further research and testing of a number of key findings would thus be valuable.

The research work culminated with validation workshops in Dar es Salaam, Lusaka and Maputo and with the development of a legal assessment report for each country (Legal assessment reports). These assessments discussed major challenges to and opportunities for, sustainable investments that are common to the four resource sectors. This paper aims to present a synthesis of these key findings.

To ground these issues, Part II discusses rule of law approaches to landscapes governance, particularly as these relate to sustainable investments. The elements of sustainable investments are analyzed, building on international initiatives that provide helpful criteria. Part III focuses on the governance and sectoral frameworks for forestry, agriculture, mining and energy in Zambia, Tanzania and Mozambique, providing the basis for the discussion in Part IV on principal challenges and opportunities for sustainable investments.

These challenges and opportunities concern incentives for sustainable investments, security of customary land tenure, the enforcement of socioeconomic and environmental safeguards and public awareness and participation. Excerpts from case studies will illustrate barriers and significant efforts to overcome these. Where appropriate, suggestions to strengthen laws, regulations and enforcement capacities are offered.

Part V captures insights and implications for future action, framed within the lens of landscapes governance and rule of law considerations. This report concludes with some final reflections in Part VI.

This synthesis paper will demonstrate that landscapes governance embodying the rule of law and adherence to social and environmental safeguards can create enabling conditions for sustainable investments. Strengthening legal and policy frameworks, coupled with improving the regulatory and governance capacity of officials and civil society, are critical to planning and managing investments so that they contribute to sustainable development. 


\section{Landscapes and rule of law: The elements of sustainable investments}

The assessment reports for Tanzania, Zambia and Mozambique examined their legal frameworks for land-use investments in the forestry, agriculture, mining and energy sectors. Suggest citing the three other CIFOR-IDLO publications here. Key research questions centered around whether and to what extent these frameworks encourage or inhibit sustainable investments.

While there is no established definition of "sustainable investments", relevant international standards suggest that these integrate socioeconomic and environmental concerns, bound together by the rule of law. The elements of a sustainable investment, as illustrated in Figure 1 and further discussed in Annex B, can provide the enabling conditions for sustainable development, equitable growth and poverty reduction.

Integrating these socioeconomic and environmental objectives in the context of development decisions requires a more comprehensive approach embodied in landscapes governance. This approach provides tools for equitably managing land in areas where other resource developments compete with environmental and biodiversity goals (Sayer et al. 2013).

A landscape is not limited to a particular space, sector or group of people. It encapsulates the complex relationships among individuals, communities and societies, including their needs and development goals and the ways in which they use resources and interact with their environments.

In order to address and harmonize the diverse and often competing interests within a landscape, effective governance is critical. Landscape governance concerns the policies, laws, regulations, institutions and decision-making processes by which activities take place, including "who has rights and benefits to what resources at what time... and who is included and excluded from activities and benefits linked to the different functions" within the landscape (Kozar et al. 2014).

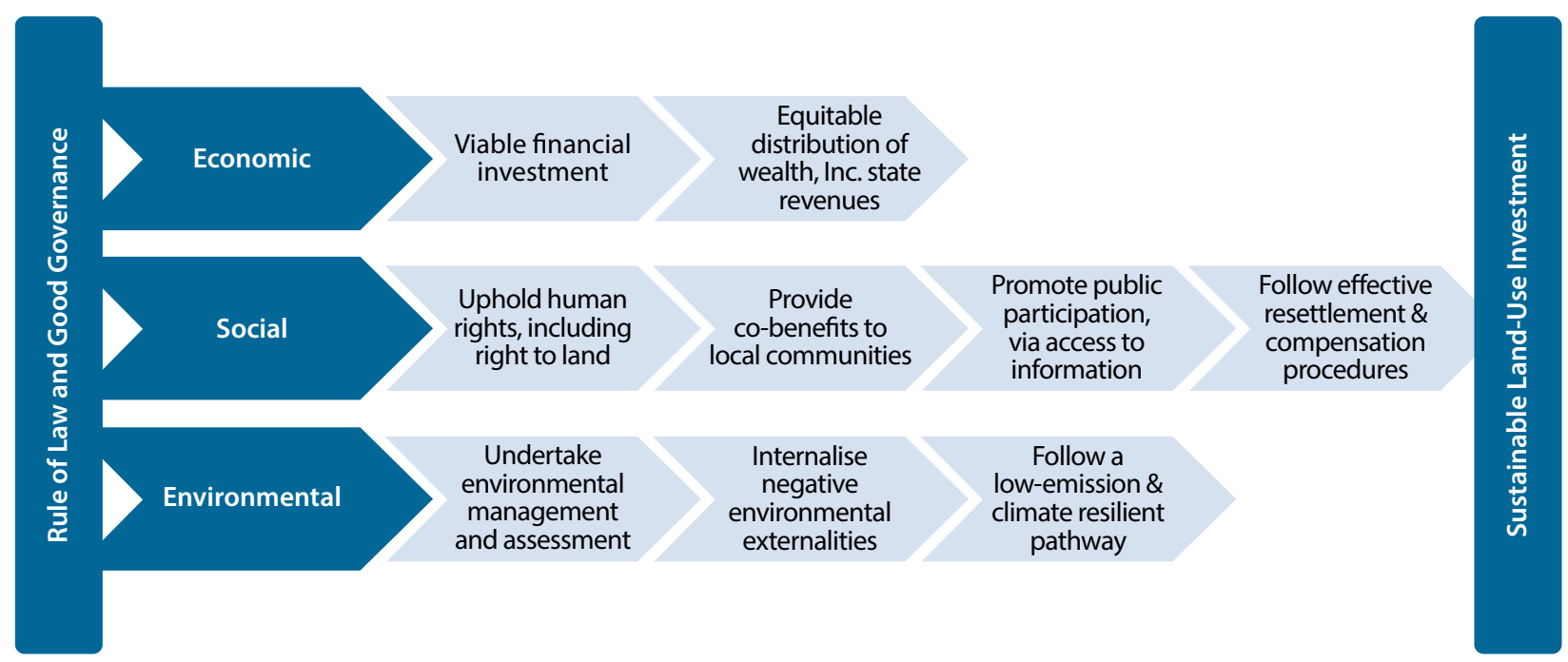

Figure 1. Illustrative elements of a sustainable investment 


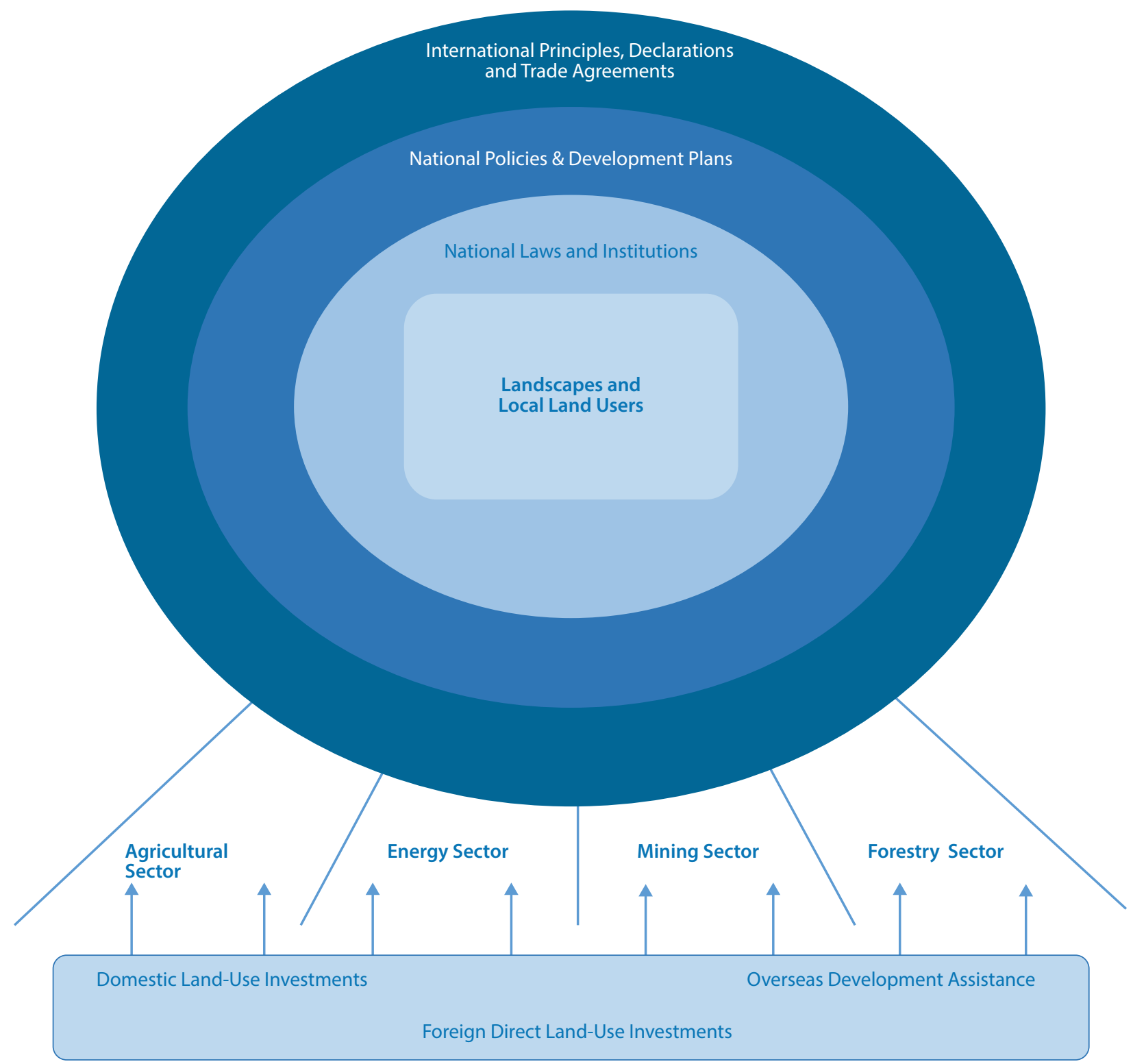

Figure 2. Landscapes governance and sustainable land-use investments

Within this governance framework, sustainable investments in forestry, agriculture, mining and energy are not viewed as isolated activities, but as multi-sectoral, multi-level and participatory. As Figure 2 illustrates, the traditional model of investment decisions based solely on economic goals and involving only the central government and an investor is broadened considerably, not only to include communities and environmental concerns but to place them at the very heart of the process.

Accordingly, all land-use sectors are linked and the governance of any one sector must be conceptualized within a broader framework for sustainable investments within the landscape. The contribution of mining, for example, will be measured not only based on revenue or employment data in that sector, but on broader development goals such as poverty reduction, food and water security, and sustainable land use.

Land-use investments that are properly managed and result in equitable and environmentally responsible development are critical for countries where large segments of the population are poor, disenfranchised and most vulnerable to the impacts of climate change. While investments may not meet all the ambitious and demanding criteria for sustainability, it is nevertheless necessary to establish good practice guidelines in order to assess the legal frameworks of countries and identify key challenges and innovations. 


\section{Laying the foundation for sustainable investments: Zambia, Tanzania and Mozambique}

Natural resources in Zambia, Tanzania and Mozambique, like most countries across the globe, are owned by the State. An overview of key statistics and challenges relating to their resource sectors provides the context for analyzing their governance frameworks for land-use investments.

Despite these countries' wealth in natural resources, poverty and resource degradation persist. A quarter or less of their populations have access to electricity, while the rest remain heavily dependent on charcoal and firewood for cooking, the burning of which is linked to health issues (Legros et al. 2009). Other serious concerns include: deforestation, forest fires, unsustainable agricultural methods, poor land-use planning, insecure land tenure, conflicting land uses and increasing population pressures.

These issues are especially challenging for communities dependent on forests for fuel, food, building materials, traditional medicines and other non-wood products. Forests sustain ecosystem services, such as water catchments and habitats for animals and insects, which in turn provide benefits for tourism, agriculture and other sectors. In Tanzania, it is estimated that these un-accounted services represent 10 to $15 \%$ of GDP (World Bank 2008).

Table 1. General overview of resource sectors (IDLO and CIFOR 2015)

\begin{tabular}{|c|c|c|c|}
\hline & Zambia & Tanzania & Mozambique \\
\hline Land area & 75.26 million ha & 88.58 million ha & 78.63 million ha \\
\hline Population & 14.08 million & 44.93 million & 23.7 million \\
\hline Forests & $\begin{array}{l}\text { - } 49.9 \text { million ha ( } 60 \%) \\
\text { - Loss of } 250,000 \text { to } 300,000 \\
\text { ha per year (0.5 to } 0.6 \%) \\
\text { - } \text { Roughly } 1.5 \% \text { of GDP }(2010)\end{array}$ & $\begin{array}{l}\text { - } 35.3 \text { million ha }(40 \%) \\
\text { - } \text { Loss of } 130,000 \text { to } 500,000 \text { ha } \\
\text { per year }(1.1 \%) \\
\text { - } \text { Roughly } 2 \% \text { of GDP }(2010)\end{array}$ & $\begin{array}{l}\text { - } 38.81 \text { million ha ( } 49 \%) \\
\text { - } \text { Loss of about } 217,800 \text { ha per } \\
\text { year (0.5\%) } \\
\text { - } \text { Roughly } 2.72 \% \text { GDP }(2011) \\
\end{array}$ \\
\hline Agriculture & $\begin{array}{l}\text { - } 31.5 \% \text { agricultural land } \\
\text { - } 20.5 \% \text { to GDP ( } 2012 \text { ) } \\
\text { - Employs } 70 \% \text { of the work } \\
\text { force ( } 92 \% \text { of rural and } 20 \% \\
\text { of urban work force) }\end{array}$ & $\begin{array}{l}\text { - } 38.4 \% \text { agricultural land } \\
\text { - } 27.7 \% \text { of GDP (2012) } \\
\text { - Employs about } 75 \% \text { of the } \\
\text { work force; smallholders } \\
\text { represent } 90 \% \text { of sector }\end{array}$ & $\begin{array}{l}\text { - } 62.5 \% \text { agricultural land } \\
\text { - } 24.9 \% \text { of GDP (2012) } \\
\text { - Employs } 80 \% \text { of the } \\
\text { population, } 70 \% \text { of whom } \\
\text { are in rural areas }\end{array}$ \\
\hline $\begin{array}{l}\text { Mining } \\
\text { (Metals) }\end{array}$ & $\begin{array}{l}\text { - Africa's largest producer of } \\
\text { copper-cobalt, with } 2 \text { billion } \\
\text { tonnes (t) in reserves } \\
\text { - } 11 \% \text { of GDP (2010); indirect } \\
\text { contribution of up to } 50 \%\end{array}$ & $\begin{array}{l}\text { - } 2 \% \text { of global gold output } \\
\text { (2010); Only producer } \\
\text { of tanzanite; produces } \\
\text { diamonds, cement } \\
\text { - } 3.7 \% \text { of GDP }(2011)\end{array}$ & $\begin{array}{l}\text { - Tantalum, marble, bauxite, } \\
\text { graphite, titanium, } \\
\text { aluminum; gold, mainly from } \\
\text { artisanal mining } \\
\text { - } 0.19 \% \text { of GDP (2011) }\end{array}$ \\
\hline Energy & $\begin{array}{l}\text { - } 70 \% \text { of energy supply from } \\
\text { biomass (charcoal and } \\
\text { firewood) } \\
\text { - Hydropower potential of } \\
\text { about } 6000 \mathrm{MW} \text {; only } 1985 \\
\text { MW has been developed } \\
\text { - Only } 25 \% \text { of the population } \\
\text { has access to electricity. }\end{array}$ & $\begin{array}{l}\text { 92\% of energy supply from } \\
\text { biomass (charcoal and } \\
\text { firewood used by } 95 \% \text { for } \\
\text { cooking) } \\
\text { - Expected to have the } 5 \text { th } \\
\text { largest gas reserves in Africa } \\
\text { - Only } 16.4 \% \text { of households } \\
\text { have access to electricity }\end{array}$ & $\begin{array}{l}\text { - } 78 \% \text { of energy supply from } \\
\text { biomass (wood, charcoal } \\
\text { and agricultural wastes); } \\
13 \% \text { of from hydropower } \\
\text { - Significant coal and natural } \\
\text { gas potential } \\
\text { - Only } 20 \% \text { of the population } \\
\text { has access to electricity }\end{array}$ \\
\hline
\end{tabular}


Deforestation is both a local problem and a global one, given its contribution to climate change. Unpredictable and extreme weather events affect the rainfall patterns relied upon by large numbers of smallholder farmers, with some of the most drastic climatic changes expected in sub-Saharan Africa. These threaten agricultural output, exacerbating existing challenges such as inefficient farming and irrigation practices.

Zambia, Tanzania and Mozambique have established general and sector-specific governance frameworks that encourage land-use investments in order to generate revenues and other benefits. Direct benefits may include increased opportunities for local employment and improved infrastructure, while indirect benefits may include technology transfer and increased competitiveness of domestic industries (Morrissey 2012; Amendolagine et al. 2013).

The general principles and strategies for land-use investments in these countries, as described in Annex C, are set forth in their constitutions and national development plans. These provide the foundation for policies, laws and programs that incorporate sustainability in the management of natural resources. ${ }^{2}$ While the central governments have broad policy-making authority and function through sectoral ministries, there is a clear trend toward decentralization. Economic growth is a principal goal, with resource investments as key drivers to that end.

Investments in these countries have increased over the last decade. This is likely due to a combination of factors, including private sector reforms, relative stability, increased demand for commodities from emerging economies, such as China and India, and a rise in biofuel demand as an alternative energy source (CIFOR 2012a). Modest socioeconomic gains are also evident. Zambia achieved lowermiddle-income country status ${ }^{3}$ with an economic growth rate of $7.3 \%$ in 2012, although its 2014 GDP decreased to $6.4 \%$. Tanzania's GDP increased

2 Constitutional reforms are pending in Zambia and Tanzania that, while largely focused on political or electoral provisions, advocate for greater protection of land, the environment, and natural resources. The outcome of both reform processes remains uncertain at this time.

3 This refers to countries with gross national income per capita of more than USD 1,045 but less than USD 12,746, according to the World Bank's classification system. See (http://data.worldbank.org/about/country-and-lendinggroups\#Sub_Saharan_Africa). slightly to $7 \%$ in 2014 from $6.9 \%$ in 2012 , while Mozambique's GDP has remained steady at $7.2 \%$ from 2012 to 2014.

Whether these countries' governance frameworks have encouraged investments is not clear, nor is the extent to which these investments have contributed to sustainable development. In spite of economic gains, they remain in the category of least developed countries, with $60 \%$ of Zambians, almost $30 \%$ of Tanzanians and $55 \%$ of Mozambicans living below the poverty line. ${ }^{4}$ Their increasing populations will place even greater pressure on systems to support social and economic development.

To assess whether these countries' land-use investments in forestry, agriculture, mining and energy embody elements of sustainability as illustrated in Figure 1, it is necessary to examine the legal frameworks for these sectors and the extent to which they interact and integrate socioeconomic and environmental concerns.

Viewed through the lens of landscape governance and as illustrated in Annex D, each of these sectors is governed by specific policies, laws and regulatory agencies. These agencies are principally focused on development activities and there is limited interaction among them. Crosscutting laws and regulatory frameworks may be found, primarily on environmental impact assessments (EIA) and investment incentives.

Opportunities thus exist for these countries to strengthen their sectoral frameworks and develop collaborative approaches to better incorporate the goals and elements of sustainable investments. Similar opportunities exist to strengthen crosssectoral mechanisms and their enforcement. Such initiatives would also be consistent with the overarching sustainability principles found in these countries' constitutions and national development plans.

The next section will build on these preliminary observations and analyze the key findings of the legal assessment reports. This will focus on the most significant challenges to and opportunities for, sustainable land-use investments.

4 UN Data (data.un.org). 


\section{Sustainable land-use investments: Key challenges and opportunities}

The legal assessment reports identified four common barriers (Figure 3) that prevent investments in the forestry, agriculture, mining and energy sectors from creating long-term, equitable value for local peoples and the country.

The following sections discuss underlying issues that cause or contribute to these barriers, including gaps or inconsistencies in laws and regulations and limited enforcement capacities. These will also highlight areas where appropriate measures may be, or are being, taken to reduce or eliminate these barriers.

\subsection{Incentives for sustainable investments}

The legal assessment reports revealed that a major challenge to sustainable investments is the lack of an effective incentive framework across the different sectors. There are several dimensions to this challenge.

\subsubsection{Land-use preferences and investment priorities}

While decentralization is a policy objective in Zambia, Tanzania and Mozambique, land-use preferences remain largely the domain of central or national authorities. In Tanzania, for example, the president is authorized under the Land Act to transfer or convert village land into general land so that it may be acquired for investment purposes. Mozambique's Mining Law allows the government to declare mineral reserves through a ministerial diploma, without requirements for public consultation or compensation.

Similarly, the authority to determine investment priorities lies with the central authorities. Mozambique's Mining Law and Regulations provide that mining is a priority land use and the Minister of Mineral Resources has the discretion to issue a reconnaissance license on the grounds of national economic interests, even in areas previously excluded for social or environmental reasons. The Tanzania Investment Act (TIA) gives the Minister of State for Investment and Empowerment discretionary authority to confer strategic investor status on projects that would then be eligible for additional benefits. Similarly, investment incentives in Zambia are provided under the Zambia Development Act (ZDA) and determined by central agencies. 
The discretion granted to central officials to determine land-use investment priorities and preferences may reduce predictability and transparency and conflict with environmental or social interests. This includes the risk of displacement and abrogation of customary land rights, especially in cases where areas may be acquired for large-scale projects.

\subsubsection{Focus on large-scale commercial investments}

Many developing countries have liberalized their legal frameworks and simplified their investment procedures through laws, agencies and programs to attract private sector - and particularly foreign - investments. This is true for Zambia, Tanzania and Mozambique. Annex F presents a comparative overview of the investment frameworks in the three countries.

The Zambia Development Agency (ZDAg) was established to facilitate private sector investments and the government's Private Sector Development Reform Programme (PSDRP) abolished price and rate controls, liberalized interest rates, harmonized the tariff structure, removed quantitative restrictions on imports, and shortened registration and incorporation processing times. The Tanzania Investment Act (TIA) established the Tanzania Investment Centre (TIC) as a one-stop shop for investors to obtain the necessary approvals, while Mozambique's Investments Promotion Centre (CPI) was created to facilitate the efficient processing of investment applications.

Registration by investors with these agencies allows them to avail of a wide range of fiscal and nonfiscal incentives. Registration involves procedures, forms and fees that are often beyond the capacity of micro, small and medium enterprises (MSMEs). This highlights the fact that these agencies and incentives are primarily designed to support large investors.

Incentives typically include: tax holidays, corporate income tax discounts or credits, deductions for capital costs, accelerated depreciation of capital equipment, deductions for foreign exchange losses, carry forward of losses and a range of value added tax (VAT)-related exemptions and other relief measures. Other incentives may be available for highly capitalized large-scale projects, such as those over USD 500,000 in Zambia and
Tanzania. These additional tax incentives can include zero or discounted tax rates on dividends and profits, duty free importation of raw materials and capital equipment and deferment of VAT on capital equipment.

With their focus on economic growth led by the private sector, investment laws do not typically mention sustainable development. They rarely include concrete socioeconomic and environmental objectives. They may, as in the case of Zambia, contain aspirational statements expressing support for MSMEs, partnerships between local and foreign investors, education and skills training and consideration of environmental impacts.

The same is true for investment treaties and investor-State agreements that focus principally on economic aspects. International investors often seek project stability through agreements between their home State and the host State of their prospective investment. Bilateral investment treaties (BITs) grant rights to foreign investors that typically include protection from expropriation, unrestricted repatriation of earnings and the right to international arbitration in the event of a dispute. These may also include other conditions deemed favorable to international investors that are beyond those provided by domestic laws, for example, waiving domestic performance requirements. As such, BITs do not typically include detailed social and environmental safeguards or the participation of MSMEs.

Whether BITs can facilitate sustainable investments remains to be seen. The BIT between Canada and Tanzania in 2013 may represent a modest step in this direction, as it prohibits derogation from health, safety, or environmental measures (Gov. of Canada n.d.). At the same time, however, it prevents Tanzania from requiring Canadian companies to procure local goods or transfer technology - contributions that would help build local markets and capacity. It also maintains the typical arbitration clause that requires disputes to be resolved through confidential and expensive proceedings.

Similarly to BITs, investor-State agreements involve a host government and a specific investor, assuring the latter security against expropriation. In the case of Zambia, Investment Protection and Promotion Agreements (IPPAs) are investor-State contracts with private Zambian or foreign investors that do 
not contain social or environmental safeguards; they involve investments of USD 10 million, again precluding the participation of MSMEs.

Investor-State agreements may contain stabilization clauses that freeze, for a fixed period or for the life of the term of the contract, fiscal or other terms as of the date of the agreement's execution. Stabilization clauses may prevent a government from enforcing improved social or environmental standards, contrary to its sovereign authority; thus, Zambia no longer officially permits these.

Mozambique's Mining law provides investors with a stability guarantee and ensures that a license or concession is recognized as a foreign or national direct investment project, for which the applicable fiscal regime will remain unaltered unless it is to the benefit of the investor. Similarly, Tanzania's Mining Act allows the Minister of Energy and Minerals to negotiate agreements with investors that guarantee the fiscal stability of a long-term mining project, particularly with respect to royalties, taxes, duties and levies.

Other than aspirational provisions encouraging local employment or best environmental practices, BITs or investor-State agreements do not mandate compliance with specific provisions on social and environmental safeguards, equitable allocation of revenue, local participation and other elements of sustainable investments. In fact, the negotiation of these agreements does not typically permit public review or input.

\subsubsection{The participation of smallholder investors}

The focus on large, commercial, land-use projects in the investment frameworks of Zambia, Tanzania and Mozambique demonstrate the continuing preference for these development options in the forestry, agriculture, mining and energy sectors. This has limited the investment incentives and opportunities for smallholders, although there are potential areas where this limitation can be addressed.

\section{Incentives for smallholders}

Tax incentives often require a minimum investment that most MSMEs cannot meet. In Mozambique, investments under USD 5000 are not eligible to register and avail of fiscal incentives, thus precluding many MSMEs from participating.
MSMEs are also confronted by other disincentives. The marginal effective tax burden on MSMEs in Zambia is $22.5 \%$, significantly higher than the tax burden on other sectors (OECD 2012). In Tanzania, taxes on smallholder farmers remain high, although the agricultural sector as a whole is the least taxed sector. Moreover, large agricultural exporters are entitled to VAT reimbursement, while small exporters are not, as they typically fall under the threshold to require registration for VAT.

The costs of registration with investment promotion agencies are often prohibitive and the procedures lengthy and tedious. There is a low level of registration among local investors and MSMEs; this is probably due to a lack of capacity and the perception that the incentives do not justify the registration process and fees. Some incentives for MSMEs may be available, although they are limited and modest. In Zambia, MSMEs with an annual turnover of less than ZMW 250 million can opt to pay a presumptive tax of 3\% instead of assessed profit from income. In addition, MSMEs that register with the ZDAg may be exempt from various taxes for limited periods, such as customs duties and income taxes.

\section{Investment opportunities for smallholders}

In contrast with the investment incentives for large-scale projects, there are few incentives in Zambia, Tanzania and Mozambique for MSMEs. MSMEs are more likely to be involved in community-based activities that facilitate public participation and can improve local livelihoods and reduce poverty.

\section{Participatory forest management (PFM)}

Tanzania's Forest Act establishes PFM to facilitate sustainable forest use by communities. PFM includes community-based forest management (CBFM), which allows villages to implement a management plan on village land, including the right to levy fines on violators and to consume or sell forest products without having to pay royalties. PFM also includes joint forest management (JFM) of forest reserves by communities or organizations and government authorities, pursuant to a comanagement agreement. JFM revenues come primarily from fines on illegal activities, such as timber harvesting in government forests and from activities such as agroforestry, ecotourism and beekeeping. 


\section{Box 1. Beekeeping in Tanzania}

Beekeeping is commonly carried out in Tanzanian forests, largely under PFM, mainly producing honey and beeswax. Although the sector annually generates about USD 1.7 million and employs about 2 million people in rural areas, beekeepers generally lack the skills and technology to meet product standards and gain access to credit and markets. The Beekeeping Act 2002 allows individuals or villages to create bee reserves that are managed by the Tanzania Forest Service and waives registration fees for harvesting on village land, a forest reserve or a community bee reserve. It establishes a beekeeping development fund for education, research and capacity building. The sector has significant potential to increase revenue while producing co-benefits, such as improved forest management and enhanced agricultural yields through increased cross-pollination. The Tanzania Forest Service and the Ministry of Agriculture, Food Security and Cooperatives do not collaborate on relevant issues, however, such as pesticide use and there are no regulations harmonizing cross-sectoral activities, including the consideration of beekeeping in EIAs.

Preliminary research suggests that CBFM has helped increase village forest incomes in Tanzania (Blomley and Iddi 2009). There are reportedly fewer JFMs, hampered by restrictions on allowable activities and the lack of clear legal guidance on the allocation of revenues. In both cases, harvesting licenses and fees are prohibitive for poorer community members (Blomley and Iddy 2009, 39). To strengthen PFM, it will be necessary to address these financial barriers and to improve the valuation of forest goods and services, including improved water catchment and other intangible benefits. Capacity building is also needed for communities to effectively participate in PFM.

\section{Charcoal production}

About $85 \%$ of urban households and $15 \%$ of rural households in Lusaka use charcoal for energy. The poorest rural households there depend on the sale of charcoal, providing a major source of employment and almost a third of their incomes. Similarly, about $90 \%$ of Tanzanians use charcoal for energy and it is the main cooking fuel in urban areas (Msuya et al. 2011).

\section{Box 2. Charcoal production in the East Arc Mountain Blocks (Schaafsma et al. 2012)}

Rural communities in the East Arc Mountain Blocks (EAM) produce an estimated 1.45 million $60 \mathrm{~kg}$ bags of charcoal - about $11 \%$ of the combined consumption of their principal markets of Dar es Salaam, Morogoro and Tanga. Their estimated total benefits amount to approximately TSH 21 billion per year (USD 14 million). Current levels of production are considered unsustainable and with the increasing urbanization and depletion of coastal woodlands around Dar es Salaam, this is expected to place even greater pressure on woodlands and forests in the EAM.

Adequate incentives and compensation schemes are needed to address unsustainable charcoal production. A recent study noted that there is little incentive to enforce charcoal-related policies due to a lack of financial resources and enforcement capacity (World Bank 2010). Moreover, the regulatory framework for charcoal production can be complex, as it is governed by the forestry and energy sectors. The Forest and Beekeeping Division (FBD) in Tanzania has primary jurisdiction over charcoal production. As wood is converted to charcoal and then used for energy, the FBD continues to manage charcoal transportation and trade, but the Ministry of Energy and Minerals becomes involved as the primary authority on energy use.

As a source of both income and energy, charcoal production will remain essential for many communities in the foreseeable future. Improved capacity and regulatory conditions can contribute to a more sustainable charcoal sector. Appropriate incentives should be established, for example, to encourage the use of energy efficient practices and kilns. The revenue allocation scheme between the central and local authorities should be reviewed and structured so that more funds can be reinvested locally for community support and monitoring. Clarity in the roles of different government agencies will also be essential, together with capacity building programs to implement more sustainable practices.

\section{Agricultural corridors and outgrower arrangements}

Incentives specifically designed to support MSMEs, together with a rational process of registration, may be explored to encourage local investments. 
In Mozambique, growth corridors have been established to create investment opportunities for sustainable agriculture and MSMEs. Support for smallholder agriculture is provided to some extent in the land law, which establishes free use and benefit of land when intended for national small-scale agricultural and livestock cooperatives and associations.

Similar programs exist in Tanzania and Zambia. The Southern Agricultural Growth Corridor of Tanzania (SAGCOT) aims to improve smallholder productivity by developing agricultural clusters that place farmers, service providers and facilities in close proximity to one another. This provides smallholders access to technology, agricultural inputs, irrigation, insurance and larger markets. SAGCOT provides financing to investors, targeting the generation of over 400,000 jobs and USD 1.2 billion of annual farming revenues.

While investments in Tanzania's agriculture sector remain limited and more government resources need to be allocated to the sector, SAGCOT can facilitate public-private partnerships and improved access to credit (Food and Agriculture Policy Decision Analysis 2014). The draft SAGCOT Greenprint or the Green Growth Investment Framework seeks to ensure that development in the corridor is environmentally stable, socially equitable and economically feasible.

The Farm Block Development Programme of Zambia seeks to expand the commercial development of wheat, sugar, cotton and other priority crops (UNCTAD 2011). The government acquires and makes land available to investors and provides basic infrastructure and services, such as roads, bridges and electricity. Each farming block is designed to have at least one core large-scale farm of 10,000 ha, several commercial farms of 1000 to 5000 ha and small farm holdings of between 30 and 3000 ha, preferably under outgrower arrangements. This system creates clusters of infrastructure, market access and inputs, such as water and fertilizer, for smallholder farmers.

Outgrower arrangements are production contracts between companies and smallholder farmers. Depending on their design and implementation, they can empower farmers as local investors, or they can perpetuate inequity. The potential risks and benefits of outgrower arrangements are illustrated below.

The KASCOL model is distinct from the typical outgrower arrangement where a company contracts farmers directly as wage laborers. The farmers in

\section{Box 3. Outgrower arrangements}

\section{The case of Marli Investments}

Marli Investments Zambia Ltd. claimed to have legally acquired 125,000 ha with more than 11 million trees and signed contracts with about 25,000 outgrowers for jatropha. These contracts were found to be disadvantageously one-sided for the farmers, allowing Marli to set prices and requiring the farmers to keep land under jatropha for 30 years and sell only to Marli. The company disappeared in 2008, with no income or benefits for the farmers.

\section{The KASCOL model}

Kaleya Smallholders Company Ltd (KASCOL) produces sugarcane in Mazabuka district in Zambia's Southern Province. It owns and manages 2,168 ha of land and sells its sugarcane to Zambia Sugar Company Plc (ZSC), which in turn sells to local and export markets. KASCOL has worked for over 30 years with the Kaleya Smallholders Trust, an association of 160 farmers that holds shares equivalent to $13 \%$ of the equity in KASCOL. The association also leases and farms about 1000 ha (4 to 7.5 ha per plot) on 40-year renewable terms from KASCOL. These long-term contracts provide the parties with greater security and a reliable income, with profits split equally and with KASCOL absorbing the risk of low sugar prices. The farmers reportedly earn on average ZMW 1900 per month, compared to an average of ZMW 250 from growing maize. Although there have been conflicts with respect to the service fees imposed by KASCOL or land claims by ZSC, the KASCOL model has largely been a success. The farmers' capacity has increased and a number of inputs have been turned over to them, including fertilizer supply and distribution. They are also producing to fair trade standards, as a result of training provided by KASCOL. The fair trade 'premium' of USD 6 per tonne goes to the Kaleya collective farmers' trust to help pay for a school bus, ambulance and other community programs. 
this case are well organized as workers and at they are also owners. It demonstrates that empowered communities with decision-making responsibilities and ownership can contribute meaningfully to sustainable investments.

Even where programs and incentives may be in place to encourage sustainable investments by local entrepreneurs and MSMEs, strong regulations and enforcement capacity are needed to prevent misuse and abuse. Simple licenses (SLs) under Mozambique's forestry laws are intended to benefit local investors, with lower requirements compared with other licenses or concessions. These SLs are vulnerable to abuse due to lack of oversight. The majority of entrepreneurial activities under SLs are unlicensed and do not comply with regulations, leading to the loss of potential State revenue and unsustainable resource use (Nhancale et al. 2009).

\section{Artisanal and small-scale mining (ASM)}

Mining licenses or certificates may be granted in Zambia, Tanzania and Mozambique for ASM. This is typically reserved for citizens and requires a relatively low capital investment. Unlike large-scale mining, very few incentives are available for ASM. One example is in Mozambique where holders of ASM certificates are exempted from paying production taxes.

Many more people and communities are engaged in ASM throughout the world, compared to largescale mining. Between 500,000 and 1.5 million are reportedly involved in ASM in Tanzania, with the government estimating that it generates at least three jobs for each individual directly involved (UNEP 2012). Between 150,000 and 400,000 are engaged in ASM in Mozambique, while the estimate is 50-150,000 for Zambia (Common Fund for Commodities 2008). Serious social and environmental issues plague the sector, including mercury use, related health issues and child labor.

ASM is an informal sector, due to the lack of appropriate legislation or ineffective enforcement of existing regulations. Programs to formalize the ASM sector and establish socioeconomic and environmental safeguards have been attempted elsewhere in Africa (CIFOR 2012b). Limited data was gathered on ASM for this project; the potential for this sector to create sustainable investment options for MSMEs merits further research and analysis.

\subsubsection{Access to credit for smallholder investors}

The lack of access to credit is evident in Tanzania's agricultural sector, which is dominated by smallholders. A 2013 OECD report notes that only about $8 \%$ of the entire rural population has access to formal financial institutions to obtain credit and only $2.4 \%$ of smallholder agricultural households borrowed money for agricultural activities. Savings and Credit Cooperative Societies (SACCOS) can provide financing for small-scale agriculture, but these are largely unavailable in rural areas and only about $16 \%$ of smallholder farmers receive credit from SACCOS.

Lack of access to credit is a key factor that perpetuates rural poverty. Smallholder access to credit in sub-Saharan Africa is generally limited due to structural factors in the finance sector and to their capacity and vulnerability issues. Lending and credit institutions, including foreign banks, are typically concentrated in urban areas and their transaction requirements and fees are beyond the reach of typical smallholders. Conversely, financial markets in rural areas are very weak or largely unavailable.

Even if credit and insurance services were available, many smallholders do not have sufficient physical or financial capital to meet collateral requirements or thresholds for credit-worthiness. Other challenges include a lack of awareness and capacity among smallholders to manage loan procedures, repayment requirements and interest rates. Moreover, smallholder farmers are among the most vulnerable to conditions that would disrupt their ability to work and to repay debt, such as extreme weather events, natural calamities, adverse health issues, economic shocks, price fluctuations and political strife.

Laws and programs are thus needed to address these capacity issues and to provide greater access to credit for vulnerable populations, especially in rural areas. Under the Kilimo Kwanza (Agriculture First) program in Tanzania, the government aims to support MSMEs by leveraging finances from public and private sources, including cooperatives, SACCOS and commercial banks. It has identified the need for legislation to regulate outgrower arrangements and to amend the Village Land Act to facilitate equitable access to land for Kilimo Kwanza investments. 


\section{Box 4. The citizens economic empowerment commission (CEEC)}

The CEEC was created by Zambian law in 2006 to empower and provide business loans to citizens marginalized or disadvantaged by race, gender, educational background, status and disability. By February 2012, CEEC had approved 1634 MSMEs and loans worth ZMW 174 million ( $\approx$ USD 28 million) for 1439 projects. With a loan recovery rate of only $42 \%$, the fund was temporarily suspended. Upon the program's resumption in early 2013, the CEEC targeted $90 \%$ of financing to rural areas and $70 \%$ to women and youth. Loans are still dominated by Lusaka and the Copperbelt, with only $35 \%$ reaching rural areas, but $20 \%$ of funds have since been provided to MSMEs wholly owned by women, with ZMW 1.6 million ( $\approx$ USD 258,500 ) provided to markets across the country estimated to have benefited more than 2000 women. In addition, $8 \%$ of CEEC funds had been provided to youth entrepreneurs.

The Citizens Economic Empowerment Commission (CEEC) in Zambia is another notable example of an initiative that aims to improve access to credit for MSMEs.

The CEEC needs greater resources to increase the capacities of its staff, especially in rural districts and achieve its loan distribution targets and recovery rate. Programs are also needed to raise awareness in rural areas about the CEEC and to help build the capacity of marginalized citizens to apply.

In general, legal reforms on banking, financial services and rural credit services to the MSMEs could be improved through a review of regulations on microfinance that can streamline governance, reporting and auditing requirements and open these institutions and their services to more MSMEs.

\subsubsection{Incentives for sustainable technologies}

Globally, fossil fuel subsidies are a major barrier to sustainable investments in low-carbon and climate-resilient development options (Holmgren 2014). Specific data on these subsidies and other similar disincentives are necessary in order to address this barrier and develop the appropriate incentives for more sustainable investments in Zambia, Tanzania and Mozambique. These would include financial incentives, such as loan guarantees and policy incentives; legal reforms may be necessary to facilitate the adoption of more sustainable technologies that typically are, at present, more risky and expensive than traditional energy investments.

While investment incentives in Zambia, Tanzania and Mozambique do not currently prioritize sustainable technologies, there are notable steps in this direction. Tanzania's Income Tax Act of 2006 allows 100\% deductible expenses for the prevention of soil erosion or to remedy damage caused by natural resource extraction. Expenses for agricultural improvement and for research and development are also 100\% deductible. These incentives can promote the use of more efficient and sustainable farming technologies. In addition, the country's Development of Small Power Project (SPP) Rules in 2010 seek to increase private sector investment in electricity generation and expand access to rural areas. SPPs are power plants using renewable energy (RE) or waste heat, or cogeneration of heat and electricity, with an export capacity of up to $10 \mathrm{MW}$. SPPs may connect to the grid and can be paid a fixed tariff for the electricity that is generated and sold to the Tanzania Electricity Supply Company (TANESCO) under a standardized power purchase agreement.

Mozambique's electricity law, Law 21/97, established the National Fund for Rural Electrification (FUNAE) to promote sustainable management of power resources and low cost options for off-grid users. It has facilitated the provision of electricity in rural areas, focusing on RE sources such as solar and mini-hydro. Zambia's Energy Regulation Act includes power generation as a priority sector eligible for specific incentives and removes VAT and excise duties on importation of solar energy equipment. Other incentives are available for biofuel and other RE sources, however, there is no readily available data on these sources in the country. This would limit the attractiveness of the sector for investors who have no guarantee of the viability of their potential RE investment.

Establishing clear, legal guidelines and investment incentives for RE, including the necessary technical, financial and information resources, are steps that can be taken to increase its development and use. 
According to the Intergovernmental Panel on Climate Change, common policies in the energy sector to incentivize RE development include feedin tariffs, quotas for RE use, preferential tax policies or exemptions and direct government payments, such as rebates and grants (IPCC 2011).

Investments in renewable and other low-carbon technologies can contribute significantly to sustainable development and entrepreneurship. In Zambia, the use of solar energy in the rural electrification program led to the installation of solar photovoltaic (PV) systems in about 400 households in the Eastern Province and in 250 chief palaces and schools. In Mozambique, FUNAE reports the successful electrification of 115 villages, 298 schools and 300 clinics through RE technologies, citing in particular the deployment of pico-scale solar energy systems.

\subsubsection{Performance-based incentives}

An environmental protection bond is a sum of money an investor must provide to guarantee compliance with environmental regulations. The bond is released if the investor is compliant, but retained to pay for any environmental damages. The bond is thus an incentive-based financial instrument to motivate and reward compliance and conversely, penalize noncompliance.

These instruments are used in both sectoral legislation and general environmental legislation. Investors in Tanzania may be required under its Environmental Management Act (EMA) to provide environmental performance bonds for certain projects, as determined by the Minister of Natural Resources and Tourism depending on the project's impacts. Its Mining Act and regulations also require holders of special mining licenses and gemstone mining licenses to post environmental rehabilitation bonds to secure the costs of mine closure.

Mozambique's environmental laws do not provide for environmental bonds, but its mining law requires the payment of mining rehabilitation bonds to cover the cost of removal of installations and of rehabilitation. Similarly, the Zambian Mines and Minerals Act also requires an environmental protection fund to secure the costs of mine closure and rehabilitation. This consists of at least 5\% of profits based on an annual audit, with moderate or poor environmental performers paying 10 and $20 \%$ respectively. In addition, Zambia’s EMA will soon operationalize an environment fund, based on a register of industrial facilities or plants whose activities have, or are likely to have, adverse environmental impacts.

Key challenges lie in ensuring that the required amounts are calculated and assessed correctly, that compliance requirements are clear and enforceable and that the mechanism can be properly implemented and monitored. Under Zambia's EMA, for example, assessing compliance with "good environmental practices" would require clear and measurable indicators.

The legal frameworks and development plans of Zambia, Tanzania and Mozambique generally favor large-scale investments, precluding participation of smallholders who are already disadvantaged by limited investment opportunities and access to credit. In the context of landscape governance and sustainable investments, greater shifts are needed not only to integrate smallholder and local community concerns in investment frameworks, but to make these their focal point. Steps in this direction are evident, among them, the expansion of PFM and incentives for sustainable technologies. Significant challenges and opportunities remain to refocus legal frameworks on sustainable investments that integrate socioeconomic and environmental objectives.

\subsection{Security of customary land tenure}

The security of land tenure is critical for natural resources investments, as it defines the right to own and use the lands on which the resources are located. The legal frameworks for resource investments in Zambia, Tanzania and Mozambique generally recognize individually documented property rights. Where, however, the land that is sought after by an investor provides the socioeconomic and cultural base for communities that have undocumented customary rights thereto, the potential for conflict arises.

\subsubsection{Transfer or acquisition of customary land}

The extent to which customary land rights are recognized in these countries vary, as do the procedures relating to their acquisition for investment purposes. Annex E summarizes key characteristics and practices pertaining to customary land rights and acquisition of these rights by third parties. In general, however, the acquisition process is driven by investors, government authorities and local leaders. 


\section{Consultation and consent}

The African Commission on Human and Peoples' Rights (ACHPR) supports the right of communities to give their free, prior and informed consent (FPIC) to natural resources projects affecting them (ACHPR 2012). FPIC is increasingly recognized as an international standard with respect to development activities within the customary lands of indigenous peoples. Recognition of FPIC and indigenous peoples is limited among African countries, with concerns that this concept may favor certain ethnic groups over others (Greenspan 2014). The ACHPR has clarified that in the African context, indigenous peoples do not necessarily refer to first inhabitants, but principally to those who self-identify as such, have a unique and collective attachment to their customary lands as a source of their identity and survival and who have been marginalized because of their distinct cultures and ways of life (ACHPR 2007).

Civil society organizations, regional institutions and others have recently increased support for FPIC in Africa, although national legal frameworks generally do not expressly recognize it (Greenspan $2014,42)$. That is the case for Zambia, Tanzania and Mozambique.

Tanzania's Village Land Act provides for partnership agreements between villages and investors and expressly states that village councils have the right to reject an application. While the FPIC concept and terminology are not used, this law clearly embodies a consent requirement.

Mozambican law is ambiguous, providing that all investors must personally consult with concerned communities to confirm whether an area is free and unoccupied before being granted a land-use right. This could implicitly refer to consent, but in implementation, the fact that the law expressly refers only to consultation negates a consent requirement. Similarly, Zambian law does not contain express language regarding consent, but requires that the chief and district council declare that they consulted community members.

Customary lands in Zambia are held in trust by the chief, who may negotiate the conversion and transfer of up to 250 ha based on his or her confirmation that the community was consulted. The village assemblies in Tanzania may approve the transfer of up to 250 ha of village land upon request by an investor, although they may also recommend that the president transfer larger areas. In Mozambique, the right to the use and benefit of land, known as a DUAT (direito de uso e aproveitamento da terra), may be transferred to third parties upon application to the provincial governor for parcels up to $1000 \mathrm{ha}$, to the Minister of Agriculture and Fisheries for land between 1000 and 10,000 ha and to the council of ministers for areas above 10,000 ha.

A notable feature of Mozambican law concerns subsistence rights of free access and use by local communities of forest resources for their own consumption, based on customary practices. These subsistence rights are legally recognized even when third parties hold licenses or concession contracts over these areas.

Despite consent or consultation requirements and other protections against unlawful transfers of customary land, communities with undocumented rights can be vulnerable to dispossession if there is low public awareness about and little transparency around, the procedures and requirements for land transfers.

In Zambia, the conversion of customary land to private land is vulnerable to abuse due to the discretion of district councils and traditional

Table 2. Community consultation requirements in the transfer of customary land (German et al. 2011)

\begin{tabular}{|c|c|c|}
\hline Zambia & Tanzania & Mozambique \\
\hline $\begin{array}{l}\text { - Chiefs and district councils } \\
\text { must declare that community } \\
\text { members were consulted. } \\
\text { - They must confirm that the } \\
\text { conversion of customary land } \\
\text { to leasehold tenure will not } \\
\text { infringe on the rights of others. }\end{array}$ & $\begin{array}{l}\text { A village assembly may question those } \\
\text { proposing to use village land under a } \\
\text { right of occupancy. } \\
\text { - The village assembly and village council } \\
\text { decide on the transfer. The Village } \\
\text { Council is also required to determine the } \\
\text { nature and extent of compensation with } \\
\text { the Commissioner of Lands. }\end{array}$ & $\begin{array}{l}\text { - Community consultation to } \\
\text { ensure land is free and without } \\
\text { occupants is required. } \\
\text { - The delineation of areas must } \\
\text { be signed by three to nine men } \\
\text { and women selected in public } \\
\text { meetings. }\end{array}$ \\
\hline
\end{tabular}


leaders to transfer land without complying with the requirement to consult the community. A comparable situation exists in Tanzania where village land may be converted to general land without consultation. A 90-day period is provided before the president effects a conversion, within which time the village council is supposed to notify those with customary rights of occupancy. Village assembly meetings should ideally be the mechanism for community consultations but the rules are not clear on their timing and the threshold for decision-making.

There are significant efforts to institutionalize community consultation requirements.

Mozambique's Land Law requires DUAT applicants to consult with concerned communities and Resolution 70/2008 requires an investor to include minutes of the consultations and the terms of its partnership with the holders of DUATs acquired by occupation. The Forest Regulations provide guidelines on consultations, including the role of the local administrator as convener and advance

\section{Box 5. Loss of customary land rights}

\section{Chikweti forests of Niassa}

The Chikweti forests of Niassa company colluded with local chiefs to develop 32,000 ha beyond their license area in Niassa, Mozambique. The communities were never consulted and the chiefs reportedly received payments and employment preference for their support. The company planted trees too close to houses and farms, blocking community expansion and sunlight. It was also found to have illegally developed prime agricultural land and naturally forested areas, depriving community access to fuelwood and medicinal products. Conflicts ensued, with communities setting fire to plantations and allowing cattle to destroy saplings.

\section{First Quantum Minerals Limited}

An agreement was entered into in 2011 by His Royal Highness Senior Chief Musele of Northwestern Zambia and Kalumbila Minerals Limited (KML), a subsidiary of First Quantum Minerals Limited (FQM), where property rights to $518 \mathrm{~km} 2$ of the Musele customary would be transferred to the company in exchange for USD 259,000 paid to the chief. This agreement was later nullified on the grounds that Zambia's Lands Act forbids any chief from selling more than 250 ha of customary land. notice of at least 15 days. The clearing of forested areas requires community consultation between DUAT holders and developers, providing however, that authorization should be issued no more than 90 days from the application's submission date.

Despite these requirements, local consultation processes in Mozambique have been subject to significant challenges, which are also evident in Tanzania and Zambia. These include:

- lack of guidance on the scope and objectives of consultations;

- uncertainty about who the community comprises;

- inadequacy of representation, especially in the case of diverse populations;

- inadequacy of notice requirements;

- insufficiency of information provided;

- language and technical information barriers;

- insufficient time periods provided;

- lack of government's implementation capacity;

- government's pressure;

- limited capacity of communities to engage and negotiate;

- exclusion of women and youth;

- dominant participation of traditional leaders and local elites who may have, or be perceived to have, ties with investors;

- unrealistic expectation of communities.

To provide greater security for communities with customary rights over their lands, clear regulations that address the foregoing challenges are necessary to ensure genuine consultation. A one-off approach with inflexible time lines and with no opportunity for interaction should be avoided. Consultation requirements that support sustainable investments should:

- ensure participation and representation of diverse groups within communities, especially women, youth and other historically marginalized groups;

- provide sufficient time for the consultation and approval processes, depending on the land area involved, the communities affected and the impacts on other sectors within the landscape;

- require timely consultations throughout the project development process, providing communities the opportunity to help shape decisions;

- require that sufficient information about a planned investment be clearly conveyed, considering language and technical issues;

- contain minimum notice, attendance and documentation requirements. 
Other mechanisms can also be considered, including the community paralegal model, where a community member is trained in basic legal knowledge and rights and can serve as the local representative with investors and other third parties. The community paralegal can also lead the documentation of customary land tenure rights.

Prescriptive provisions and mechanisms, together with the establishment of policies and procedures for local consultations, can provide more guidance for government authorities, investors, traditional leaders and communities on consultation processes that respect customary land rights holders and users.

\section{Limitations on foreign ownership}

The emphasis of investment incentives on largescale investments, which are often by foreign companies, coupled with the insecurity of customary land rights, may render customary lands even more vulnerable to misappropriation or usurpation. In an attempt to reduce foreign use of land, the recent constitutional review process in Zambia included a proposal to limit land acquisition by foreigners to the period of their proven investment, instead of the possible 99-year lease. Under the current law, land in Zambia can be leased to both nationals and foreigners for largescale investments. The Zambian Law Development Commission also recommended that citizens be given priority in land allocation for investment in customary land areas.

In Tanzania, foreign investors can obtain land rights for investments through the TIC's land bank system. The land title reverts to the TIC at the end of the investment project. The land banking system is not yet fully operational due to the lack of availability of land and lack of resources to provide compensation in the conversion of village land to general land. Notwithstanding these challenges, the system conceptually has the potential to streamline the administration of land for foreign investments. It could ensure that only land designated for foreign investment is available for acquisition by foreigners and thus provides an additional safeguard against land grabs.

\subsubsection{Documentation of customary land rights}

The insecurity of customary land rights often arises from their lack of formalization or documentation. Only 8000 land titles are registered in Zambia and

\section{Box 6. Vulnerability of undocumented land rights to fraud}

Fifty smallholder farmers in Zimpeto in the Infulene Valley in Maputo were dispossessed of their land, which was 'sold' by an intermediary who claimed to represent the farmers. The buyer allegedly paid MZN 120 million (about USD 5000) and obtained a provisional title. The farmers did not have the resources to take the case to court.

registration is costly, administratively cumbersome and subject to outdated standards (Mason-Case 2011). Mozambique's land law requires verification of existing rights and recording of land interests in the national land cadastre, yet land titles in hundreds of cases have been granted to investors over areas previously identified as communities' lands.

Undocumented customary rights are often excluded in conventional land registration systems. This renders customary landholders vulnerable to fraud and dispossession.

Transparent and effective documentation of customary land rights is needed, together with access to reliable land information for rights holders and investors. An audit system has been proposed in Zambia to compile information on land ownership, as well as an electronic registry system to monitor land transactions. Certification programs are likewise underway, and there is a pending Customary Land Tenure Bill seeking to title customary land and secure the rights of rural communities.

In Tanzania, each village council is required to maintain a register of village land that interested parties can inspect. Village land may not be acquired by foreigners. The TIC is tasked to acquire lands to manage a land banking system and to facilitate transfers to investors. This system may ensure that only village land legitimately converted to general land is in the land bank, thus protecting village land from being unscrupulously converted or acquired by third parties. It is unclear, however, how the TIC will acquire sufficient lands to comprise its land bank.

Formalization of customary land rights - whether by titling, registration, recording or certification can potentially increase the security of customary land tenure, but these should be carefully 
scrutinized. These processes can be circumvented by wealthy and local elites who are more familiar with registration systems. They are also typically costly, time-consuming, bureaucratic and centralized, rendering them inaccessible to low income and rural communities, whom they are predominantly targeting.

Further dialogue and understanding about these different options and their implications are needed, including an assessment of land and resource values, as well as the capacities that communities would need to formalize their rights while respecting customary laws and processes. Further research would also be helpful on approaches and models used by other countries to address similar issues.

\subsubsection{Displacement and resettlement}

Resettlement must be viewed as a last option in development projects, occurring only in the most compelling circumstances. It must be carried out with the informed consent of affected communities, in a consultative manner that provides for genuine, equitable compensation and that does not result in increased impoverishment.

Large-scale land acquisitions for agricultural use in Tanzania have given rise to widespread claims of land grabbing and displacement of local customary land users. Zambia's legal framework is silent on resettlement rights in the event of displacement due to land acquisitions for investments. The only resettlement policy in place applies to natural disasters. Government agencies often revert to the World Bank's guidelines on resettlement (World Bank 2004).

Mozambique issued its Regulation for Resettlement Resulting from Economic Activities in 2012. While it provides important protections on housing and other specific elements, it lacks guidance with respect to livelihoods, grievance mechanisms, community consultation and other critical issues. Mozambique's Mining Regulations require compensation in cases of resettlement but the amount is subject to negotiation. Communities that lack negotiation capacity are disadvantaged and more vulnerable to dispossession, especially when they are unaware of their rights with respect to resettlement.

The absence of clear and enforceable regulations means that the terms and conditions for resettlement will ultimately depend on the discretion of government authorities and investors.

\section{Box 7. Displacement of Capanga villagers}

The queen of Capanga village and some members of her community refused the offer of resettlement by Companhia Vale do Rio Doce (Vale) and Rio Tinto to Mualadzi. The queen wanted the entire community to be moved together only after construction work was completed and basic services were available. Instead, she claimed that pressure was exerted to relocate and that 40 families were moved ahead to Mualadzi where there were no services. Children and the sick had to walk $5 \mathrm{~km}$ to schools and clinics in the Vale resettlement compound of Cateme. Water was scheduled to be brought into the village via truck twice a week but this was unreliable. Other pledges reportedly went unfulfilled, including paved roads and land for farming and employment.

Southern Africa Resource Watch (SARW)

This will likely result in inequitable resettlement conditions and even increased hardships for displaced communities.

Unlike Zambia and Mozambique, Tanzanian law requires an agreement on compensation between the land rights holder or the village council and the commissioner of lands prior to converting village land to general land. Compensation can be monetary or through a land exchange, based on the market value of the land and improvements thereon. It includes a disturbance allowance, transport allowance, accommodation allowance and loss of profits. Despite local requirements and international standards, operational challenges remain.

It is important that clear operational guidelines are established that internalize social safeguards on involuntary resettlement due to land-use investments. Beyond or in addition to policies set by international finance institutions, broader international standards of the UN and other organizations can provide further guidance (UN 2010). Consideration must be made for actual physical displacement and for economic displacement, where people lose access to sources of livelihood such as forests, land to grow crops, or to water sources. The calculation of compensation must be carried out in an inclusive and culturally sensitive manner, considering land access and use arrangements, community structures, site-specific criteria and genuine alternatives for sustainable livelihood options. 


\section{Box 8. Failed compensation arrangements}

\section{Sun Biofuels}

Sun Biofuels compensated 152 households for land taken from Kisarawe village in Tanzania. Official compensation values did not consider all land uses. A government valuation sheet was used, which did not, for example, cover income from leasing trees and other activities. Moreover, rice crops were not considered because the valuation was conducted in March, when there was no evidence of rice cultivation (Oakland Institute 2011).

\section{Derema corridor}

The community in Derema in the East Usambaras, which form part of the Eastern Arc Mountains in Tanzania, was primarily engaged in farming. Theirs was village land and as such, the law recognized their rights and required compensation in case of revocation, compensation to any villager occupying land under a customary right of occupancy, whether that customary right of occupancy is registered or not. The Derema Corridor was later established as a protected area, and included farmland of the community. To identify those entitled to compensation, teams of surveyors called farmers onto their fields. Each plant was counted and recorded on a form together with the person's reported name and photograph. No other data was collected and women were not consulted. Personal checks were later given out to the people listed during the valuation, with no guidance regarding distribution to the household or use of the funds. Compensation was paid only for the standing crops on the land and not the land itself (Rantala et al. 2013).

Compensation and resettlement agreements with clear, binding terms can provide equitable parameters for valuation and safeguards against breaches. Negotiations require consultations and an understanding by the community of land-use rights and the legal implications of transfers of title. The absence of customary or government authorities tasked with ensuring that the negotiation process is fair and that communities are fully informed is a critical barrier to ensuring their protection. Mechanisms should thus be put in place to build community awareness and understanding of land rights and land values, as well as community capacity to negotiate for their own interests.

\subsubsection{Mechanisms for dispute resolution}

Access to appropriate and effective dispute resolution mechanisms for land conflicts and environmental issues are important safeguards to protect rights to land and increase security of title. The land and environmental laws of Zambia, Tanzania and Mozambique generally provide community level and judicial avenues for dealing with disputes.

The effectiveness of dispute resolution approaches relies on a number of factors, including clear implementing regulations. Concrete guidance is needed, for example, on the "Mozambican forum" that would oversee a particular case, consistent with the country's policy objective to strengthen community and district tribunals to address conflicts related to DUAT titles (National Land Policy 1995). In addition to the lack of clear regulations, authorities are also constrained by limited financial resources and technical capacity to carry out their responsibilities.

For rural communities, lack of awareness about legal rights and limited financial resources are key challenges. Bringing a case before a forum or a tribunal can be costly and time-consuming; thus, mechanisms are needed that address these barriers and provide access to justice for those with limited resources. The Zambian Lands Act 1995 established the lands tribunal as a mobile court to provide low-cost and accessible dispute resolution for land-use conflicts. However, lack of awareness among rural communities about this tribunal has reduced its effectiveness. In addition, it is limited to addressing statutory land cases and does not have jurisdiction to hear disputes arising on customary land. As a result, the most common method for resolving land disputes continues to be through the local traditional leaders.

Safeguards are thus needed to ensure that those tasked with dispute resolution, including local leaders and civil authorities, are neutral, credible and qualified. This will be critical in addressing inequities within the community and with respect to third parties. 
Table 3. General frameworks for dispute resolution (German et al. 2011)

\begin{tabular}{|c|c|c|c|}
\hline & Zambia & Tanzania & Mozambique \\
\hline $\begin{array}{l}\text { Land disputes, including } \\
\text { land claims, benefit } \\
\text { rights and complaints } \\
\text { about land decisions }\end{array}$ & $\begin{array}{l}\text { - Lands Tribunal } \\
\text { - Supreme Court } \\
\text { (Lands Tribunal Rules 1996; } \\
\text { Customary Tenure Conversions } \\
\text { Regulations 1996) }\end{array}$ & $\begin{array}{l}\text { - Village Land Councils } \\
\text { - Judiciary } \\
\text { (Village Land Act 1999) }\end{array}$ & $\begin{array}{l}\text { A Mozambican forum, } \\
\text { with community } \\
\text { participation in rural } \\
\text { areas (Land Law 1997) }\end{array}$ \\
\hline $\begin{array}{l}\text { Environmental disputes, } \\
\text { including complaints } \\
\text { about environmental } \\
\text { permits }\end{array}$ & $\begin{array}{l}\text { Environmental Council of Zambia } \\
\text { (ECZ) } \\
\text { (Environmental Protection and } \\
\text { Pollution Control Act 1990) }\end{array}$ & $\begin{array}{l}\text { Environmental Appeals } \\
\text { Tribunal (Environmental } \\
\text { Management Act 2004). }\end{array}$ & $\begin{array}{l}\text { Courts of law } \\
\text { (Environmental Law } \\
\text { 1997) }\end{array}$ \\
\hline
\end{tabular}

Sustainable investments uphold human rights, including rights to land. Where land is held by communities under customary law and practices, this necessarily involves the duty to consult them, gain their consent and respect their right to participate in decisions concerning the use of the land and benefits therefrom. Communities are at greater risk of losing their customary rights to land when transparent consultation processes are lacking.

Customary land rights, especially when undocumented, are vulnerable to fraud and elite capture, not only at the national level by powerful or moneyed groups, but also at the local level by community leaders. Significant opportunities thus remain to strengthen protection of customary land rights in the governance frameworks of Zambia, Tanzania and Mozambique. These include appropriate mechanisms that: ensure broader consultation with community members beyond traditional leaders, provide more secure recognition of customary land rights, establish stringent and enforceable regulations on displacement and compensation and provide greater access to justice for impacted communities. In the context of landscape governance, these protections and mechanisms are critically needed in order to uphold human rights, community rights to land and to enable sustainable investments.

\subsection{Enforcement of socioeconomic and environmental safeguards}

Zambia's EMA, Mozambique's law on environment and Tanzania's EMA incorporate the polluter pays principle, public participation and other principles of sustainable development. These require an environmental assessment for proposed projects and whether a broader EIA is required depends on the scale and impacts of a project. Mining projects and other large, industrial activities typically require a full EIA.

The extent to which social and environmental safeguards are integrated in sectoral frameworks varies. For example, Mozambique's Forest and Wildlife Act calls for management that conforms to the principles of conservation and sustainable use. Tanzania's Forest Act requires sustainable management and stakeholder consultations. While the current forestry framework in Zambia has limited reference to sustainability, their proposed new Forests Bill would recognize CBFM, JFM with customary communities and mechanisms under the United Nations Framework Convention on Climate Change (UNFCCC).

Sustainable investments require environmental responsibility, public participation and respect for human rights. While the sectoral and crosscutting legal frameworks of Zambia, Tanzania and Mozambique integrate various elements of sustainable investments, substantive gaps and process-based barriers exist in the enforcement of socioeconomic and environmental safeguards.

\subsubsection{Multi-jurisdictional issues and institutional coordination}

Pursuant to sector-specific laws, government institutions overseeing the countries' forestry, agriculture, mining and energy sectors are subject to separate mandates. These mandates include distinct development strategies that can result in inconsistent or confusing government actions with respect to different uses of the same areas. 
Competing mandates and overlapping jurisdictions may also weaken social and environmental safeguards. The establishment of protection zones is one such example. Mozambique's land law authorizes the government to establish these for conservation or preservation activities, but it also gives the provincial governor and the Minister of Agriculture and Fisheries the discretionary authority to issue special licenses within these areas. At the same time, the council of ministers may modify or even extinguish protection zones.

Similarly, the Zambian president has the authority to unilaterally revoke previously declared forest reservations.

Harmonizing the different applicable laws is fundamental to the promotion of sustainable investments. Fragmented laws on incentives, for example, can make it challenging to assess the effectiveness of these incentives and investor compliance. Governments can consider mechanisms to harmonize incentives or consolidate these into a centralized investment law, to reduce overlaps, increase predictability and transparency in the application of incentives and safeguards.

Similarly, clarifying government mandates and harmonizing the responsibilities of institutions are critical in enforcing social and environmental safeguards to mitigate adverse impacts of landuse investments. Beyond mitigation objectives, more focus is also needed on institutional capacity to capture and maximize benefits from these investments, especially for concerned communities.

\section{Box 9. Overlapping land designations in the Massingir pistrict of Gaza province}

A 30,000 ha area in the Massingir District of Gaza province in Mozambique was covered in 2007 by an investment agreement between ProCana Limitata and the Government of Mozambique for sugarcane cultivation, ethanol production, construction of an electricity plant and an outgrowers scheme. At the same time, it had also been reserved by the Limpopo National Park to facilitate a resettlement program for communities displaced from the park. To add to the competing uses, the area was already inhabited by grazing communities, villages and subsistence farmers, despite assertions to the contrary by the Director of District Service for Economic Activities (FIAN International 2010).

\section{Box 10. Withdrawal of the Lusaka South Forest Reserve 26}

In 1985, the Lusaka South Forest Reserve 26 was degazetted by the president due to urbanization in Lusaka and opened up for development. Robert Chimambo of the Zambia Climate Change Network affirmed: "Sadly, the proposed location of the Multi Facility Economic Zone in Forest Reserve 26 will mean the destruction and degradation of the forest, which is right on top of the Lusaka aquifer. This would also mean poisoning the rivers and the ground water..."(Chiombe 2013).

Strengthening coordination among agencies with expertise on water, energy, forestry, finance and other sectors - through a designated agency or through an interagency mechanism - can spread the burden more evenly of assessing, monitoring and evaluating investor compliance and project benefits. This will require a review of institutional capacities and mandates, legislative or regulatory mechanisms to clarify and coordinate responsibilities and focused capacity building efforts for government staff across agencies.

Potential collaborative mechanisms may already be in place. In Mozambique, the inter-ministerial National Council for Sustainable Development (CONDES) and the Ministry for the Coordination of Environmental Affairs would be ideally suited for strengthening institutional collaboration. One of the challenges will be to overcome the perception that environmental management is an obstacle to investment decisions" (Cabral and Francisco 2008). In Zambia, the ZDA may be well placed to evaluate the sustainability of investments. Its current screening role can be expanded to add criteria for sustainability.

\subsubsection{Enforcement capacity and political will}

The legal assessment reports demonstrate that the frameworks of Zambia, Tanzania and Mozambique incorporate principles of sustainability in their constitutions and development plans. Environmental and social safeguards for land-use investments in the different sectors are principally found in environmental laws and regulations. The capacity and commitment to enforce these safeguards remains a major challenge to the sustainability of land-use investments. 


\section{Monitoring compliance with safeguards}

Inadequate human and financial resources limit the number of environmental inspectors and their capacity to monitor investments. In Zambia, environmental audits are typically undertaken only every 3 years. The regulators' staffing needs are constrained by uncompetitive conditions of service resulting in high staff turnover. Staffing constraints are also evident in Mozambique, where there were reportedly only 364 forest enforcement agents within the National Directorate of Land and Forest (DNTF) in 2006, about one agent per 111,000 ha of forest (UNCTD 2012).

The monitoring of forest management plans (FMPs) in Mozambique is similarly impacted; based on 2008 data from the DNTF, only 81 out of 165 forest concessions - less than half -have submitted their FMP. A FMP is a legal prerequisite for forest licenses and concessions and it must have been prepared with the local community - this is an important social and environmental safeguard that is undermined by lack of enforcement.

Inadequate inspection and monitoring mean that investors may avoid compliance with social and environmental safeguards, or even fail to implement their investment activity altogether. Additional funding from the national treasury would be essential, supplemented by international grants or by environmental fees and other financial instruments.

\section{Decentralized governance}

The devolution of governance functions to local authorities is an express objective in Zambia, Tanzania and Mozambique and it is an important strategy aimed at facilitating more effective monitoring of investments. This is complex and challenging, however, given the insufficiency of financial and human resources to fully implement decentralized governance.

District councils in Zambia have been given greater responsibilities without additional funding, in some cases, leading to poor service delivery. This is particularly the case for rural districts with even lower levels of revenue. While a Local Government Service Commission was created to strengthen capacity of personnel, training can be hampered by the multiplicity of laws and regulations applicable to the different councils.
The reality is that the governance of the resource sectors remains highly centralized. The national departments or ministries are principally responsible for implementing sector-specific laws and developing regulations. They are often solely responsible for making decisions on investment applications, issuing licenses or concessions and monitoring investors' compliance with legal requirements.

Zambia’s Forest Department, Ministry of Agriculture, Mines Development Department and Energy Regulation Board promulgate regulations, evaluate investment applications and collect license fees. They also regulate and monitor investor compliance with legal requirements. The Mines Development Department, for example, is responsible for ensuring that a mining project avoids wasteful practices, the breach of which may result in termination of the investor's mining rights.

As is common in most countries, the hierarchy for investment decisions in Zambia, Tanzania and Mozambique depends on the size and scale of the proposed investment. A provincial governor in Mozambique issues SLs for areas up to 405 ha and forest concession contracts for up to 20,000 ha. Forest concessions for larger areas are the responsibility of the Ministry of Agriculture or the council of ministers. Similarly, mining passes and mining certificates for ASM are issued by the provincial director of mining, while all other licenses and concessions covering larger areas are the responsibility of the Minister of Mineral Resources, who is not required to consider the views or recommendations of provincial or local authorities.

The increasing scale and complexity of a land-use investment typically means that a larger number of communities will be impacted. And yet it is when the investment and impact are potentially larger that the decision-making becomes even more centralized and the participation of local authorities and the public diminishes. Effective devolution of enforcement authority would require the harmonization of national and subnational laws and regulations, as well as strengthened financial and human resources at the local level.

\section{Political will}

Environmental agencies may be subject to financial and political pressures or to discretionary decisions made by other agencies. The lack of government 


\section{Box 11. Mining in the Lower Zambezi National Park}

The Lower Zambezi National Park is a protected area that generates revenue from safaris and tourism. It is also the site of Zambezi Resources' proposed USD 494 million Kangaluwi copper mining project. According to the then International Union for the Conservation of Nature (now The World Conservation Union), the Lower Zambezi National Park is "one of the few pristine wilderness areas left in Africa." A government official stated, "..most of Zambia's oil and gas reserves are found in game management areas. So how do we handle these issues... we have to weigh the advantages of having an economic project against environmental protection."

The Zambia EMA found that the company's EIA did not adequately address environmental and social costs, including the impact of the open pit on groundwater levels. It rejected the EIA in August 2013, which also nullified the company's mining license. This decision was reversed by the Minister of Environment in January 2013 upon the company's appeal. The case was brought before the Lusaka high court, which issued an injunction the following month that has halted mining prospects in the park.

commitment and political will to enforce socioeconomic and environmental safeguards is a major barrier to sustainable investments.

In Zambia, there are efforts to mainstream environmental concerns and climate change across all ministries. The challenge of balancing and integrating socioeconomic and environmental concerns is very difficult, particularly in the face of powerful, competing interests.

There remains a general bias towards quantity and value of investments, potentially disregarding longterm risks, impacts and benefits beyond an election cycle. Political will is especially needed when confronted with competing interests over land that pit, rather than integrate, economic interests against environmental values. Strong advocates or champions committed to sustainable development options are needed in government, civil society and the private sector.

\subsubsection{Environmental and social regulations}

The environmental laws of Zambia, Tanzania and Mozambique recognize the right to public consultation and access to information in the EIA process as a key social safeguard. The EIA process generally requires the environmental agency to evaluate the terms of reference submitted by an investor. The analysis stage involves a baseline study, project description, environmental and socioeconomic impact evaluation and reasonable alternatives. EIA regulations provide guidelines for public consultations with all persons likely to be affected by a proposed project. Advance notice of consultation is typically required, together with dissemination of project information.

\section{Adequacy of operational guidelines}

The lack of adequate guidelines for enforcing social and environmental requirements leads to implementation gaps that are then left to the discretion of the government or the investor. Sustainable investments require the operationalization of social and environmental safeguards through robust, clear and effective regulations.

Zambia adopted more robust social and environmental safeguards in their 2011 EMA but, in the absence of new EIA regulations, continues to use the outdated regulations of 1997. DUAT authorizations in Mozambique are issued provisionally to safeguard against investors' failure to undertake their projects, but there are no regulations for monitoring compliance or for revocation (Deininger et al. 2010). Their EIA regulations require advance notice for public consultations and the dissemination of technical reports in major land uses and in all cases involving relocation or the restriction in the use of natural resources, but there are no specific guidelines on operationalizing these requirements.

Socioeconomic safeguards are also needed for the appropriate calculation and collection of revenues. Under Mozambique's Mining Law, mining operations are subject to a production tax based on the sale price of the mining products. Appropriate regulations can help monitor transfer pricing and ensure that the government is recovering fair revenues from the sale of products to associated companies. These regulations should be clear and enforceable and provide detailed guidance to investors with respect to transfer pricing risks. 


\section{Consistency of EIAs and conformity with global standards}

Although the EIA process is well established in Zambia, Tanzania and Mozambique, the number of EIAs undertaken is sporadic and focused more around developed areas. This may be due to greater investments in these areas and easier access to project areas through better roads. Evidence also indicates that low public awareness about EIAs, limited government personnel and EIA consultants and constrained funding resources contribute to the inconsistent application of EIAs, especially in rural areas.

In some cases, investments have been exempted from the EIA process even when critical environmental issues were involved. In Mozambique, a USD 2 billion hydroelectric dam downstream of the Cahaora Bassa dam was approved in August 2010 without an EIA (Norfolk and Cosijn 2011). In Zambia, only large-scale agricultural projects with irrigation schemes of more than 50 ha are required to undertake an EIA, despite their cumulative environmental and social impacts on sustainable land use. In cases of large-scale land-use investments, strategic or programmatic EIAs that consider broad and cumulative impacts should be the norm.

International finance institutions, including multilateral development banks - such as the World Bank Group and the Africa Development Bank (AfDB) - require application of their environmental and social impact assessment (ESIA) policies for major investment projects. Projects financed in the past 4 years by the AfDB in Zambia have all produced ESIAs (AfDB 2014).

Environmental agencies in all three countries could review their environmental and sectorspecific against these and other global standards on EIA. Mozambique's law on investments, for example, requires activities that emit levels of pollution likely to negatively affect the environment or public health to comply not only with domestic laws but also with international agreements to which Mozambique is a signatory. This provision could allow for investors to be subject to more stringent provisions than those provided for in the domestic framework, although the regulations are silent on how this mechanism should be implemented.

\section{Time frames for the evaluation of investments}

In Tanzania, a certificate of incentives is required to avail of fiscal incentives. This is issued by the TIC, which also assists investors obtain the necessary approvals from other government agencies, such as the Ministries of Labour, Industry and Trade and Lands and Human Settlement Development. Under the Investment Act, these agencies have only 14 days to render a decision on a project application; otherwise approval will be deemed granted.

While Mozambique's law on investments expressly incorporates sustainable development goals, government officials have only 3 days to evaluate the environmental and social impacts of an investment of up to USD 100 million and 10 days for projects exceeding that amount. Approval will also be presumed if no decision is made within these time frames.

These restrictive periods imposed to expedite investment decisions are inconsistent with the goal of thoroughly assessing the sustainability of a project. They are especially inadequate for largescale investments involving complex impacts on communities and on landscapes. They can preclude meaningful consultations with communities and other stakeholders that means that that social and environmental concerns may be sacrificed.

\section{Qualification of consultants}

An investor must hire an accredited or recognized independent consultant to undertake the EIA. Tanzania's EMA provides stringent requirements on certification and disciplinary processes. Eligibility requirements for citizens include a relevant academic degree and references and are even more stringent for foreigners. Approved experts are certified and must renew annually and are included in a register available to the public.

Similarly, Mozambique's regulations allow only specialists with a degree and 5 years of experience to undertake EIAs. Registry certificates are granted where proof can be shown of suitable qualifications and must be updated every 3 years. The lack of capacity of government staff to undertake the certification process has hindered the implementation of this requirement; the lack of qualified consultants could negatively impact the quality of the EIA process (Kakonge 2006). 
In contrast, Zambia's EIA regulations do not provide criteria on determining competence and independence and there is no formal certification process. There is thus a need to improve oversight of these consultants.

The EIA process may be viewed as flawed because the consultant is selected and financed by the investor, raising the question of bias and an incentive to downplay the impacts of a project. To address these issues, national or intergovernmental mechanisms to train and certify EIA consultants can be established. This would improve the quality of consultants and address the potential conflict of interest that is possible under the current system. It would also build local institutional capacity to undertake environmental and social impact assessment work.

\subsubsection{Allocation of benefits}

Resource-related conflicts can arise when communities impacted most by land-use investments have no role, participation or benefits therefrom. The situation is worse when communities experience even greater hardship due to large-scale land acquisition by third parties. For investments to be sustainable, they should result in an equitable distribution of wealth and in cobenefits for affected communities.

Legal requirements that entitle local communities to a share of investment revenue are rare; they can be a powerful socioeconomic safeguard to strengthen the position of communities and to ensure that the benefits they receive do not solely depend on their capacity to negotiate.

A clear example of this is Mozambique's Ministerial Order 93/2005, which requires benefit-sharing as a component of the application process for SLs and as part of the terms of forest concession contracts. Local communities are entitled to $20 \%$ of all the fees levied for forest exploitation. They are required to register community management committees (CGCs) to represent them and establish a fund to receive the payments. These payments are distributed to communities living in the areas where forest resource extraction is taking place and are allocated by dividing the total payment by the number of beneficiary communities. Communities must designate three members of the CGC to manage the accounts on behalf of all members. CGCs are required to prepare annual reports outlining the accounts and the activities undertaken with community funds.

The regulations omit critical guidance, however, on what comprises the fees levied and do not provide communities access to information on how much developers earn in forest resource extraction. This makes it very difficult for communities to verify whether payments received have been calculated correctly.

A study showed that a total of 558 communities had received payments by 2010 amounting to MZN 60 million (USD 2.4 million) (Trusen et al. 2010). It further found that these revenues contributed to the communities' greater sense of ownership and pride. They managed the funds, often prioritizing schools, other social infrastructure, income generating activities and conservation.

PFM is another approach that can empower and generate tangible benefits for communities. In Tanzania, PFM covers $12.8 \%$ of the country's forests, and has created investment opportunities for communities while enhancing forest management in degraded forests. More efforts will be needed to expand PFM, especially where it can provide better alternatives to unsustainable practices, such as illegal charcoal production. PFM expansion will also require improvements in gathering reliable and comprehensive data on forest resources in order to evaluate the impact of management strategies.

The crosscutting environmental laws of Zambia, Tanzania and Mozambique incorporate social and environmental safeguards, principally through the EIA process and project monitoring requirements. Such safeguards are increasingly (albeit unevenly) evident in sector-specific laws. Socioeconomic safeguards that entitle and grant communities an equitable share of investment revenues or benefits are far more limited.

While the inclusion of safeguards in environmental and sectoral legislation is a positive step toward creating the conditions for sustainable investments, their effectiveness is hampered by significant challenges discussed herein. These include competing and even conflicting government mandates, limited enforcement capacity and gaps or inconsistencies in laws and regulations governing the four resource sectors, as well as in crosscutting laws on the environment, taxation and 
investment incentives. In the context of landscape governance and sustainable investment objectives, opportunities thus remain to clarify and streamline government mandates, strengthen institutions and interagency collaboration, harmonize national and subnational laws for decentralized management, address legal and enforcement capacity gaps and develop equitable revenue allocation mechanisms that can genuinely capture and sustain benefits for affected communities.

\subsection{Public awareness and participation}

While governments are charged with promulgating and enforcing laws, the participation of other stakeholders - including civil society, communities and the private sector - is necessary to create the conditions for sustainable land-use investments. An engaged, educated public is better able to make informed decisions on matters that affect them. Without adequate information that is publically available, it will be challenging for citizens to actively engage in decision-making processes and to hold traditional leaders, government authorities and investors accountable. Governance systems require transparent mechanisms for public consultation and participation.

\subsubsection{Participatory land-use planning}

Sustainable investments promote public participation and participatory land-use planning (PLUP) - an approach to development and management that supports this goal. PLUP is an iterative multi-stakeholder process of dialogue aimed at evaluating land-use options and determining equitable and sustainable uses of land. It emphasizes community interests, the exchange of information and partnerships among diverse stakeholders. As such, it can support capacity building for communities, develop collaborative mechanisms and serve as a forum to address disputes.

Mozambique and Zambia do not have laws expressly on PLUP, although aspects thereof may be found in varying degrees, particularly in the forestry sector. Mozambique has established PFM that involves communities in forest management planning. Zambia has adopted integrated landuse assessment to develop baseline information and monitor forest resources. While this aims to strengthen capacity in forest management planning and address issues that may arise in REDD+ implementation, it may also contribute to broader PLUP efforts.

In contrast, PLUP has been carried out at the village level in Tanzania, first under PLUP guidelines issued by the National Land Use Planning Commission and later under its Land Use Planning Act. It has enabled a number of communities there to strengthen their rights over customary lands and natural resources (IIED 2010) and it can maintain flexibility across larger areas according to traditional adaptive management practices in semiarid environments.

PLUP efforts in Tanzania have the potential to rationalize resource use rights amongst competing local groups, such as farmers and livestock keepers. While it can strengthen local groups amidst external pressures, conflicts continue in certain areas as local bylaws and land-use plans are disregarded. PLUP efforts thus need to be linked and respected across governance levels. The preference of national and local elites for largescale commercial land-use investments remains a source of uncertainty for PLUP and for customary land rights.

\subsubsection{Consultation and participation in the EIA process}

The EIA process requires public consultations with concerned stakeholders. In Tanzania, the regulations specifically require publication of the notice in a newspaper with national circulation, radio advertisements and recorded minutes of the public meeting. The National Environmental Management Council (NEMC) may hold additional hearings and is required to solicit comments from affected individuals. The resulting environmental impact statement must include a nontechnical executive summary in both English and Swahili of key findings and recommendations.

Zambian regulations include provisions to ensure that public views are taken into account not only during the EIA process but also in the preparation of the terms of reference of the EIA. In general, however, guidance is unclear with respect to the scope and identification of people likely to be affected. The discretion of government authorities and investors to interpret this can limit, rather than broaden, participation. Marginalized groups 


\section{Box 12. BioCarbon Partners' (BCP) Lower Zambezi REDD+ Project}

$\mathrm{BCP}$ is a majority African-owned private company piloting the first REDD+ demonstration project in Lower Zambezi, Zambia, to reduce poverty and enhance forest conservation. REDD+ can potentially eliminate rural livelihoods if traditional forest uses, such as charcoal, are prohibited. Lower Zambezi communities are very poor and dependent on fuelwood for energy, subsistence agriculture and charcoal production for sale to urban markets. BCP and the local communities developed a partnership that adhered to the community wellbeing requirements of the international climate, community and biodiversity alliance standard. This required extensive documentation of project impacts and demonstrated benefits, including community leadership, empowerment and equitable benefit-sharing. BCP undertook and documented a comprehensive baseline survey of households, extensive community meetings over 1 year and continued community engagement and monitoring.

This partnership was formalized through community covenants - communities committed to reduce unsustainable forest activities in exchange for project investment and employment. One example is the Sustainable Eco-Charcoal Project partnership, where the community produces the eco-charcoal product, while BCP provides the kilns, training, market access, transportation and other operational needs.

such as women and youth and the lowest levels of the community, are most vulnerable to exclusion, particularly in the context of formalized and hierarchical structures. In Zambia, the Chief must first be consulted and agree before an EIA consultant can approach the community members.

The dissemination of information to stakeholders is often inadequate, preventing dialogue and understanding of a proposed project. Translation of EIA documents into easily understandable language is limited. Moreover, investors are not typically required to assess social impacts, or to consider measures to mitigate these impacts. Zambia's Annual State of Human Rights Report of 2010 finds that in many investor-led public hearings, the focus is primarily on social and economic benefits without detailing possible negative consequences. This was also found to be the case in Mozambique.

Adequate representation at consultations, timely dissemination of information and awareness of cultural sensitivities, can significantly impact the public consultation process. For the process to contribute to sustainable investments, situationspecific considerations should be taken into account. These include comprehensibility of information, inclusion of vulnerable and marginalized groups, objective presentation of information, language and location. Community consultations are best conducted in local languages and at venues near project areas, rather than in city centers. It is critical that public comments and concerns are genuinely documented and considered.

This case demonstrates that early, continuous and genuine engagement with communities to understand their social, livelihood and environmental needs can contribute to joint and mutually beneficial planning of an investment.

\subsubsection{Access to environmental and social information}

EIA regulations in Tanzania provide that documents related to EIAs should be public, although access to these shall be on terms established by the NEMC. The discretionary authority of NEMC undermines the right of access.

Zambia's EMA last issued a State of Environment Report in 2008 and a National Environmental Action Plan in 1994. The latest State of Human Rights report was published by the Human Rights Commission in 2010. While the consolidation and publication of these reports is a positive step that can increase public awareness about environmental and social issues, their delayed issuance and infrequency limit their utility.

Constraints in funding and human resources have hindered the timely production of these reports. The commitment to produce these reports remains an important goal that is worth emulating in other countries. The consolidation and analysis of social and environmental data will help build the capacity of government authorities and increase awareness among the general public. 
Financial and technical assistance can be explored to support relevant agencies in producing quality reports in a timely manner. Assistance can also support the creation or improvement of online portals that can be accessed by citizens through their computers and mobile phones, to help disseminate information about investments and their impacts. In Zambia, the development of a free, online portal focusing on climate change is underway.

Collaboration with academic and research institutions as well as civil society groups focused on environmental protection, social concerns and natural resource management, can also promote greater awareness and monitoring of landuse investments.

\subsubsection{Freedom of information}

Tanzania's constitution guarantees the right to disseminate information and to be informed at all times of important events and issues. Their 2006 Freedom of Information Bill proposes to set up administrative mechanisms to implement the right of access. This remains pending, as do similar laws in Mozambique and Zambia. Freedom of information legislation has been considered in Zambia for more than 10 years.

While there are no freedom of information laws, the countries' crosscutting environmental laws ensure access to environmental information. Zambia's EMA is required to provide public access to paper copies of environmental information and to maintain a registry of relevant environmental laws, treaties, policies and reports. EIA applications and licenses are also included in the registry, although only a limited number of these are currently available. Similarly, documents related to an EIA in Tanzania are public pursuant to their EIA and Audit Regulations of 2005, though their disclosure is subject to conditions set by the National Environmental Council. The right of access to environmental information in Tanzania is limited to publicly held information and subject to a number of exceptions, including impacts on public order, national security, trade and industrial secrets and where the request is vague or manifestly unreasonable.

While the right to environmental information is recognized in the different laws related to EIAs in the three countries, these do not include commercial, financial or other data related to investment applications, investors and business operations. Sustainable investments require transparency and yet there are no laws in these countries that guarantee access to this information.

Broader freedom of information laws could improve access to noncommercial confidential information about investments. Access to such information would help build the capacity of civil society and the public to hold investors, traditional leaders and government authorities accountable.

Consistent with the International Covenant on Civil and Political Rights and the African Charter on Human and Peoples' Rights that strongly support the right to information and which all three countries have ratified, freedom of information legislation should be pursued. This would also improve access to information concerning applications for land acquisition and land-use investments decisions, including issues on displacement, compensation and resettlement. Publically available information and strengthened capacity of civil society to scrutinize investments could empower the citizens of Zambia, Tanzania and Mozambique to hold investors and decisionmakers to account for their actions.

At the same time, these countries can participate in multi-stakeholder voluntary initiatives focusing on transparency and access to investment information. The Extractive Industries Transparency Initiative (EITI) - a multistakeholder initiative currently implemented by 48 countries which promotes transparent management of natural resources - requires reporting, publication and reconciliation of the payments that extractive companies in participating countries make with the revenues received by governments. All three countries are compliant with EITI requirements, having issued comprehensive and publicly accessible reconciliation reports that provide important and timely investment information not otherwise available. This is another positive example of the influence and role that international standards can have in strengthening domestic legal frameworks.

Sustainable investments promote public participation through access to information. The legal frameworks of Zambia, Tanzania and 
Mozambique vary with respect to the extent they incorporate this objective. While PLUP approaches are not legally established in Zambia and Mozambique, notable examples may be found in Tanzania. Crosscutting EIA regulations include requirements to provide information and consult with concerned stakeholders, although both regulatory and enforcement gaps limit genuine access to information and informed participation.
Updated environmental information and data regarding specific investment projects is limited and no laws recognizing freedom of information have been passed. Landscape governance and sustainable investment objectives call for greater focus on improving access to information and to strengthening participatory approaches to land-use planning and decision-making around investment projects. 


\section{Implications of key findings for future action}

Legal frameworks for sustainable investments require the institutionalization and effective enforcement of socioeconomic and environmental safeguards. In examining the legal frameworks of Zambia, Tanzania and Mozambique with respect to land-use investments in the four resource sectors, it is clear that they have taken significant steps in this direction.

In all three countries, their constitutions and national development plans espouse principles of sustainability. They have developed national strategies on climate change and corresponding governance mechanisms. Decentralization of government functions to improve service delivery and local participation is a common policy objective. Crosscutting environmental legislation and sectorspecific laws recognize EIAs as a legal prerequisite for major projects and increasingly recognize other environmental and social safeguards. While much more limited, there are seminal efforts to develop incentives for low-carbon options and to increase investment opportunities for MSMEs.

It is important to build on this progress by addressing the significant challenges identified in Part IV that hinder land-use investments in these countries from contributing to poverty alleviation and sustainable development. Table 4 presents a summary of the rule of law considerations for strengthening legal frameworks and institutions and for empowering communities.

This project to assess the legal frameworks for forestry, agriculture, mining and energy in Zambia, Tanzania and Mozambique has documented experiences and observations on large-scale landuse investments in these sectors. In doing so, it has enabled a deeper understanding of legal and enforcement challenges and highlighted rule of law approaches to landscapes governance that government and other stakeholders may consider to create enabling conditions for sustainable investments. These include (IDLO 2014):

- Assessments of legal and institutional frameworks for different sectors within a country - These will help identify the extent to which these frameworks adhere to the elements of sustainable investments, including provisions conforming with acknowledged international standards, legal and regulatory gaps or constraints and overlaps in institutional mandates.

- Institutional strengthening - This includes programs that address technical or knowledge constraints within institutions, increase transparency and accountability and establish mechanisms for institutional coordination.

- Policy formulation and legal reforms - These initiatives aim to strengthen skills in developing sound policies and responsive laws that provide the foundation for the effective implementation of sustainable development objectives, including incentives and penalties for violations.

- Regulatory enforcement - This supports the development, drafting and implementation of clear and effective rules that implement laws, including the detailed design of appropriate incentives and compliance monitoring.

- Negotiation skills - This aims to strengthen the capacity of stakeholders to analyze and frame different perspectives on an issue, respectfully consider options to arrive at mutually beneficial outcomes and accordingly draft contracts or other legal instruments that reflect agreed processes and outcomes.

- Participatory processes - These include multistakeholder mechanisms that recognize the relevance and importance of each voice, that foster dialogue and engender trust and that build capacity through the exchange of information and sharing of experiences.

- Dispute settlement - This includes the study of different systems for resolving conflicts, their applicability and appropriateness, 
access to justice for marginalized groups and implementation of liability, claims and compensation processes.

To build on the legal assessments and the findings discussed in this report, our next steps should specifically include capacity-building programs in Zambia, Tanzania and Mozambique to support implementation of rule of law approaches discussed above and summarized in Table 4. Similar legal assessments may be extended to other sectors and to other countries in the developing world.
Subsequent action will depend on country interest, availability of resources and validation of programmatic need through scoping missions.

While the key findings and options identified here are principally directed at the governments, it is equally important and necessary to involve all other stakeholders. Strengthening legal frameworks and the capacity of governments and civil society are critical for managing investments so that they contribute to sustainable development.

Table 4. Strengthening legal frameworks, building institutions and empowering communities for sustainable investments

\section{Incentives for sustainable investments}

\section{Reframe investment incentives}

- Integrate safeguards in the investment framework

- Incorporate safeguards in investor agreements and BITs

- Evaluate the feasibility of consolidating investment incentives in one law

- Establish reasonable time frames for the approval of investments by government authorities

- Improve data on RE sources in the country

- Assess and expand policies to incentivize low carbon development options

\section{Focus on smallholder interests}

Develop broader investment incentives for MSMEs Streamline registration costs and requirements for MSMEs Strengthen community-based mechanisms in sectoral laws Provide capacity building for communities for PFM Develop legal guidance on revenue allocation in PFM Improve the valuation of forest goods and services, including improved water catchment and other intangible benefits

Clarify government roles in charcoal production

Develop appropriate incentives and compensation schemes to encourage sustainable practices in charcoal production

Facilitate knowledge sharing with other countries about innovative programs to improve investment frameworks for MSMEs and strengthen their access to credit Review regulations on microfinance; streamline governance and reporting requirements for MSMEs Develop programs to raise public awareness about available credit facilities, especially in rural areas

\section{Enforcement of environmental and}

Socio-economic safeguards

Establish clear and effective safeguards

- Ensure the consistent and harmonized integration of safeguards in sectoral legislation

- Provide clear and measurable indicators in regulations

- Establish mechanisms to review the exercise of discretionary authority to reclassify land

- Review EIA regulations against global standards

- Develop national or intergovernmental mechanisms to train, certify and improve regulatory oversight of EIA consultants

- Establish transparent mechanisms to verify the calculation of taxes, royalties and other payments by investors

- Collect and make available information on fees levied on investors and revenues generated by projects

- Establish mechanisms to ensure equitable allocation of resource revenues to affected communities

\section{Strengthen enforcement capacity}

- Mainstream responsibility for safeguards among agencies

- Increase funding for training and enforcement of social and environmental safeguards

- Explore sources of funds for training and enforcement, including the national treasury, international grants or environmental fees and other market-based instruments.

- Strengthen enforcement capacity to monitor compliance with laws and regulations

- Ensure that performance bonds are assessed correctly

- Strengthen coordination among agencies with expertise on water, energy, forestry and other sectors through a designated agency or through an interagency mechanism

- Identify and support advocates or champions in government, civil society and the private sector who are committed to sustainable development 
Table 4. Continued

\begin{tabular}{ll}
\hline Incentives for sustainable investments & $\begin{array}{l}\text { Enforcement of environmental and } \\
\text { Socio-economic safeguards }\end{array}$ \\
\hline & $\begin{array}{l}\text { Support decentralization } \\
\text { - Harmonize national and subnational laws and } \\
\text { regulations }\end{array}$ \\
- Strengthen financial and human resources at the local \\
level \\
- Review allocation of revenues from resources \\
between national and local authorities \\
- Structure revenue allocation so that more funds can \\
be reinvested locally for community support and \\
monitoring
\end{tabular}

Security of customary land tenure

\section{Protect customary land rights}

- Assess options for the documentation of land rights, including research on approaches adopted in other countries

- Provide access to land information for rights holders and investors

- Assess the effectiveness of local mechanisms to resolve land disputes

- Ensure that only land designated for foreign investment is available for acquisition by foreigners

- Establish clear policies and guidelines on involuntary resettlement that internalize socioeconomic and environmental safeguards

- Establish mechanisms to build community awareness and understanding of land rights and land values, as well as community capacity to negotiate for their own interests

\section{Facilitate community consultations}

- Ensure participation and representation of diverse groups within communities, especially women, youth and other historically marginalized groups

- Provide sufficient time for the consultation and approval processes

- Require timely consultations throughout the project development process

- Require that sufficient information about a planned investment be clearly conveyed, considering language and technical issues

- Provide minimum notice, attendance and documentation requirements

- Consider innovative mechanisms, such as training for a community paralegal who can represent the community with third parties and document customary land rights
Public awareness and participation

\section{Raise public awareness}

- Consolidate, analyze and publish social and environmental data to build government capacity and increase public awareness

- Explore financial and technical assistance to support production of timely environmental reports

- Create publicly accessible online portals for socioeconomic and environmental information and investment projects

- Collaborate with academic or research institutions and civil society groups to promote greater awareness and monitoring of land-use investments

\section{Guarantee freedom of information}

- Pursue freedom of information laws to improve access to investment-related information and empower citizens to hold investors and decision-makers accountable

- Strengthen commitment to international and multistakeholder initiatives that promote transparency and access to information

- Publish project-related agreements, including investment agreements and community agreements 


\section{Concluding remarks}

Sustainable landscapes governance requires multilevel arrangements that integrate the different functions and interests in land around the rights and concerns of affected communities. The effectiveness of these arrangements depends on balancing divergent and often competing land uses and development perspectives at the community, local, national and even international levels.

Certain themes recur throughout this report that illustrate many of the key challenges sought to be addressed by sustainable landscapes governance. These challenges include the multifunctional nature of landscapes with overlapping and competing interests, the centralized nature of decisionmaking authority over land use and investment priorities and the preference for large-scale landuse investments in rural areas. They also focus on the vulnerability of customary land rights to elite capture, technical and financial capacity constraints of governing institutions and limited public awareness of rights and access to information.

These challenges reflect the very realities that marginalize people and perpetuate the trap and cycle of poverty, particularly among rural communities. In the context of these challenges, what is landscapes governance and how can it be realized? How can traditional systems of topdown, sectoral governance transition to sustainable landscapes governance? What does it mean to place communities at the center of sustainable investments and development?

This report identifies and discusses rule of law considerations - such as equity, transparency and public participation - that shed light on these questions. Legal reforms or increased enforcement capacity that can enable landscapes governance will fundamentally depend on a transformative shift in development attitudes and priorities, from economic-centered land use to more holistic governance that equally considers social and environmental values.

Enabling this shift is fundamental to landscapes governance that can create, in turn, the conditions for sustainable investments. Cross-sectoral capacity development initiatives are needed that focus not only on strengthening legal and technical skills, but on fostering dialogue and refocusing development perspectives.

Capacity building initiatives and other rule of law measures discussed throughout Part IV and summarized in Table 4 are not simple, one-off activities. Their effectiveness is contingent on sustained and active engagement that can help transform attitudes around community-centered landscapes governance. Long-term investments in capacity building, institutional strengthening and policy development are necessary; welldesigned participatory mechanisms that have the potential to foster dialogue and collaboration among different stakeholders around development concerns are equally important.

The rule of law and landscapes governance can drive reforms that pursue sustainable investments as enablers of genuine human development. This is possible only by situating the interests of the poor and most vulnerable communities at the center of development decisions. 


\section{References}

[ACHPR] African Commission on Human and Peoples' Rights. 2012. Resolution on a human rights-based approach to natural resources governance. http://www.achpr.org/ sessions/51st/resolutions/224/.

[ACHPR] African Commission on Human and Peoples' Rights. 2007. Advisory opinion of the African Commission on Human and Peoples' Rights on the United Nations Declaration on the Rights of Indigenous Peoples.

[AfDB] African Development Bank. 2014. Environmental and social impact assessments (ESIAs). http://www.afdb.org/en/documents/ environmental-social-assessments/ environmental-and-social-impact-assessmentsesias/zambia/

Amendolagine V, Boly A, Coniglio N, Prota F and Seric A. 2013. FDI and local linkages in developing countries: Evidence from subSaharan Africa. Development Policy, Statistics and Research Branch. Working Paper 7/2012. Vienna: United Nations Industrial Development Organization (UNIDO).

Arezki R, Deininger K and Selod H. 2012. The Global Land Rush. Finance \& Development. http://www.imf.org/external/pubs/ft/ fandd/2012/03/pdf/arezki.pdf.

Blomley I and Iddi S. 2009. Participatory forest management in Tanzania: 1993-2009: Lessons learned and experiences to date. Ministry of Natural Resources and Tourism. Forestry and Beekeeping Division of the United Republic of Tanzania Report.

Cabral L and Francisco D. 2008. Environmental institutions, public expenditure and the role for development partners: Mozambique case study final report. Overseas Development Institute.

Castrén T, Katila M, Lindroos K and Salmi J. 2014. Private financing for sustainable forest management and forest products in developing countries: Trends and drivers. Washington, DC: Program on Forests (PROFOR).
Chao S. 2012. Forest peoples: Numbers across the world. Forest People's Programme.

Chiombe E. 2013. Waiting for the Rains, Zambia Grapples with Climate Change. Inter Press Services News Agency. 29 December 2013. http://www.ipsnews.net/2013/12/waitingrains-zambia-grapples-climate-change/.

[CIFOR] Center for International Forestry Research. 2012a. Bioenergy Infobrief No. 54: Bioenergy, Sustainability and trade-offs: Can we avoid deforestation while promoting biofuels? Bogor: CIFOR.

[CIFOR]. Center for International Forestry Research. 2012b. The formalisation of artisanal mining in the Democratic Republic of the Congo and Rwanda report. Bogor: CIFOR.

Common Fund for Commodities. 2008. Regional workshop: Small-scale mining in Africa. 2008. A case for sustainable livelihood. http://www.commonfund.org/fileadmin/ user_upload/Repository_docs/CFC_Report_ Mining_2008_final_2_.pdf.

Deininger K, Byerlee D, Lindsay J, Norton A, Selod H and Stickler M. 2010. Rising global interest in farmland: Can it yield sustainable and equitable benefits? World Bank Publications. Washington, DC.

FIAN International. 2010. Land grabbing in Kenya and Mozambique - A report on two research missions - and a human rights analysis of land grabbing.

Food and Agriculture Policy Decision Analysis. 2014. Country fact sheet of food and agriculture policy trends: United Republic of Tanzania.

German L, Schoneveld G and Mwangi E. 2011. Contemporary processes of large-scale land acquisition by investors: Case studies from subSaharan Africa. CIFOR Occasional Paper \#68.

Government of Canada. Foreign Affairs, Trade and Development Canada. n.d. Agreement between the Government of Canada and the Government of the United Republic of Tanzania 
for the Promotion and Reciprocal Protection of Investments. http://www.international.gc.ca/ trade-agreements-accords-commerciaux/ agr-acc/fipa-apie/tanzania-text-tanzanie. aspx?lang=eng.

Greenspan E. 2014. Free, prior, and informed consent in Africa: An emerging standard for extractive industry projects. Oxfam America Research Backgrounder Series.

Holmgren PH. 2014. Climate Leader Papers. Climate Action, [UNEP] United Nations Environment Programme. Mainstreaming emission reductions across the landscape. http:// www.climateactionprogramme.org/climateleader-papers/mainstreaming_emission_ reductions_across_the_landscape

[ICSG] International Copper Study Group. 2013. The World Copper Factbook 2013. http://www. icsg.org/index.php/component/jdownloads/ finish/170/1188.

[IDLO] International Development Law Organization and [CIFOR] Center for International Forestry Research. 2015. Enabling legal frameworks for sustainable land use investments. Legal Assessment Reports for Zambia, Tanzania, and Mozambique.

[IDLO] International Development Law Organization. 2014. Doing justice to sustainable development, International Development Law Organization. http://www.idlo.int/sites/ default/files/pdfs/Doing\%20Justice\%20to\%20 Sustainable\%20Development\%20report.pdf.

[IIED] International Institute for Environment and Development. 2010. Participatory land use planning as a tool for community empowerment in northern Tanzania. London: IIED.

[IPCC] Intergovernmental Panel on Climate Change. 2014. Synthesis report of the fifth assessment report: Summary for policymakers.

[IPCC] Intergovernmental Panel on Climate Change. 2011. Special report of the IPCC. Renewable energy sources and climate change mitigation. 198.

Kakonge J. 2006. Environmental planning in sub-Saharan Africa: Environmental impact assessment at the crossroads, Working Paper No. 9. New Haven, CT: Yale School of Forestry \& Environmental Studies.

Kozar R, Buck LE, Barrow EG, Sunderland TCH, Catacutan DE, Planicka C, Hart AK and Willemen L. 2014. Toward viable landscape governance systems: What works? EcoAgriculture Partners, on behalf of the Landscapes for People, Food, and Nature Initiative.

Washington, DC.

Legros G, Havet I, Bruce N and Bonjour S. 2009.

The energy access situation in developing countries: A review focusing on the least developed countries and sub-Saharan Africa. [WHO] World Health Organization and [UNDP] United Nations Development Programme.

Mason-Case S. 2011. Legal preparedness for REDD+ in Zambia: Country study. Rome: IDLO.

Morrissey O. 2012. FDI in sub-Saharan Africa: Few linkages, fewer spillovers. European Journal of Development Research 24(1):26-31.

Msuya N, Masanja E and Temu AK. 2011. Environmental burden of charcoal production and use in Dar es Salaam, Tanzania. Journal of Environmental Protection 2(10):1363-9. doi:10.4236/jep.2011.210158

National Land Policy. 1995. Mozambique.

Nhancale BA, Mananze SE, Dista NF, Nhantumbo I and Macqueen DJ. 2009. Small and medium forest enterprises in Mozambique. IIED Small and Medium Forest Enterprise Series No. 25. Maputo, Mozambique: Centro Terra Viva and London: IIED.

Norfolk S and Cosijn M. 2011. Development and the balancing of interests in Mozambique. In Faure M and du Plessis W, eds. The Balancing of Interests in Environmental Law in Africa. Pretoria, South Africa: Pretoria University Law Press.

Oakland Institute. 2011. Understanding land investments in Africa: Tanzania.

[OECD] Organisation for Economic Co-operation and Development. 2012. Investment policy reviews: Zambia.

[OECD] Organisation for Economic Co-operation and Development and [IEA] International Energy Agency. 2012. World energy outlook 2012. IEA Publications. http://www.iea.org/ publications/freepublications/publication/ WEO2012_free.pdf.

Rantala SE, Vihemäki H, Swallow BM and Jambiya G. 2013. Who gains and who loses from compensated displacement from protected areas? The case of the Derema Corridor, Tanzania. Conservation and Society 11(2): 97-111.

Sayer J, Sunderland T, Ghazoul J, Pfund J-L, Sheil $\mathrm{D}$, Meijaard E, Venter M, Boedhihartono AK, Day M, Garcia C, et al. 2013. Ten principles for a landscape approach to reconciling agriculture, conservation, and other competing land uses. Proceedings of the National 
Academy of Sciences of the United States of America 110(21):8439-56. doi:10.1073/ pnas. 1210595110

Schaafsma M, Morse-Jones S, Posen P, Swetnam RD, Balmford A, Bateman IJ, Burgess ND, Chamshama SAO, Fisher B, et al. 2012. Towards transferable functions for extraction of non-timber forest products: A case study on charcoal production in Tanzania. Ecological Economics 80:48-82.

Trusen C, Calengo A and Rafael B. 2010. A study of the development and implementation of strategies for sustainable local land management based on practical experience. Part 1: Mozambique. GIZ.

[UN] United Nations 2010. United Nations basic principles and guidelines on development-based evictions and displacement.

[UNCTAD] United Nations Conference on Trade and Development. 2013. World investment report. http://unctad.org/en/ PublicationsLibrary/wir2013_en.pdf.

[UNCTAD] United Nations Conference on Trade and Development. 2012. Investment policy review.

[UNCTAD] United Nations Conference on Trade and Development. 2011. An investment guide to Zambia: Opportunities and conditions.
[UNEP] United Nations Environment Programme. 2012. Analysis of formalization approaches in the artisanal and small-scale gold mining sector based on experiences in Ecuador, Mongolia, Peru, Tanzania and Uganda: Tanzania case study.

Vorley B, Cotula L and Chan M. 2012. Tipping the balance: Policies to shape agricultural investments and markets in favour of small-scale farmers. Research Report Summary. IIED and OXFAM. http://www.oxfam.org/sites/www. oxfam.org/files/rr-tipping-balance-agriculturalinvestments-markets-061212-summ-en.pdf.

World Bank. 2010. Enabling reforms: A stakeholderbased analysis of the political economy of Tanzania's charcoal sector and the poverty and social impacts of proposed reforms.

World Bank. 2008. Country study: Putting Tanzania's hidden economy to work: Reform, management, and protection of its natural resource sector.

World Bank. 2004. Involuntary resettlement sourcebook: Planning and implementation in development projects. Washington, DC.

World Rainforest Movement. 2012. An overiew of industrial tree plantations in the global south: Conflicts, trends, and resistance struggles. EJOLT, Report No. 3. 

CIFOR Occasional Papers contain research results that are significant to tropical forest issues. This content has been peer reviewed internally and externally.

The International Development Law Organization (IDLO) and the Center for International Forestry Research (CIFOR) assessed the legal frameworks for major natural resource sectors in Zambia, Tanzania and Mozambique to analyze whether, and to what extent they enable sustainable investments.

National development plans in each country, and their crosscutting laws on land and the environment incorporate principles of sustainable development. However, sector-specific laws governing forestry, agriculture, mining and energy reflect these principles to varying degrees. Relying significantly on natural resources, these countries have witnessed consistent GDP growth in recent years. Despite their resource wealth and increased investments, poverty and resource degradation persist. Rural populations remain disproportionately affected, with limited access to basic services and increased vulnerability to the impacts of deforestation and climate change.

This Synthesis report outlines four key insights on issues identified by the legal assessments that can either hinder or enable sustainable land use investments. These consist of

- Reframing investment incentives and focusing on smallholder interests;

- Protecting customary land rights and ensuring consultation and consent:

- Establishing clear and effective regulations, strengthening enforcement capacity and supporting decentralization and

- Raising awareness, guaranteeing participation and promoting freedom of information.

The report demonstrates that landscapes governance embodying the rule of law and adherence to social and environmental safeguards can create enabling conditions for sustainable investments. Equity, responsive legal and policy reforms, improved enforcement capacity, strengthened participatory mechanisms and other rule of law considerations are critical to planning and managing investments so that they contribute to sustainable development.

\begin{tabular}{|l|l|l|} 
RESEARCH & $\begin{array}{l}\text { This research was carried out by CIFOR as part of the CGIAR Research Program on Forests, Trees } \\
\text { PROGRAM on }\end{array}$ \\
Forests, Trees and Agroforestry (CRP-FTA). This collaborative program aims to enhance the management and \\
age of forests, agroforestry and tree genetic resources across the landscape from forests to farms. \\
Agroforestry
\end{tabular}

